\title{
Benthic Macroinvertebrate Susceptibility to Trout Farm Effluents
}

\author{
Lenn Darrell Roberts
}

Thesis submitted to the faculty of Virginia Polytechnic Institute and State University in partial fulfillment of the requirements for the degree of

Master of Science

In

Environmental Science and Engineering

Greg Boardman, Chairman

Reese Voshell

Andrea Dietrich

August 30 ${ }^{\text {th }}, 2005$

Blacksburg, Virginia

Keywords - trout effluents benthic macroinvertebrates artificial substrates Hyallela 


\title{
Benthic Macroinvertebrate Susceptibility to Trout Farm Effluents
}

\author{
Lenn Darrell Roberts
}

(ABSTRACT)

\begin{abstract}
The direct effects of a Virginia trout farm on benthic macroinvertebrates were examined using multiple approaches. Static laboratory tests with the amphipod, Hyallela azteca, were conducted with exposures to water taken from a spring, effluent above a sedimentation basin, and effluent below a sedimentation basin. On-site mesocosms were constructed to expose previously colonized artificial substrates to the same treatments as the laboratory tests. Flat-headed mayflies were also collected from a nearby stream and transported to the mesocosms for a 10 day exposure. There was no significant difference between treatments in the laboratory tests after 20 days, but after 28 days the control was significantly lower than the above sedimentation basin treatment in one test. In the multispecies field tests, a clear decrease in total invertebrate abundance and EPT abundance was seen in the effluent treatments compared to the spring water treatments, with a slight improvement in survival in the treatment below the sedimentation basin. However, only total invertebrate abundance after 21 days produced statistically significant differences. A significant difference was detected between the effluent and the spring treatments in the flat-headed mayfly field test. We suggest that the effects seen in this study do not explain the lack of taxa richness in the receiving stream. The main cause of mortality from trout effluents appears to be solids accumulating upon the organisms, and sedimentation basins should be effective best management practices for protecting macroinvertebrates.
\end{abstract}

Keywords-trout effluents benthic macroinvertebrates artificial substrates Hyallela 


\section{Acknowledgements}

The authors would like to thank the Commercial Fish and Shellfish Technology (CFAST) at Virginia Tech for financial support for all research conducted.

I would like to thank my committee members: Drs. Boardman, Voshell, and Dietrich. I had previously taken one course with each of them at Virginia Tech, and I had a great experience with all of them both in their classes and during the research process. They were the best advisory committee I could have had.

This project is dedicated to Mom, Dad, Danny, and Sarah Murray, who I helped me get through the most difficult times of the work. 


\section{Table of Contents}

Chapter I: Literature Review .............................................................................................1

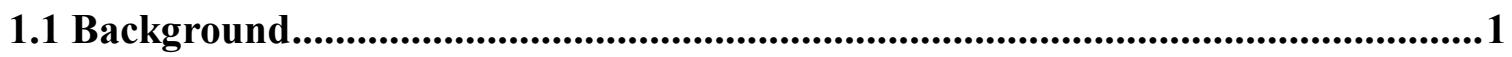

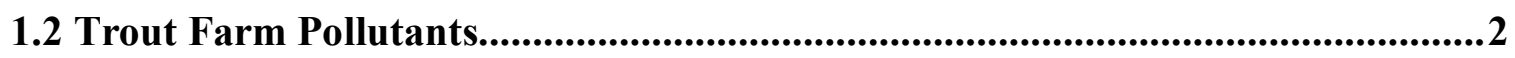

1.3 Trout Farm Effects on Macroinvertebrates ...................................................................5

1.4 Methods for Assessing Pollution on Macroinvertebrates............................................9

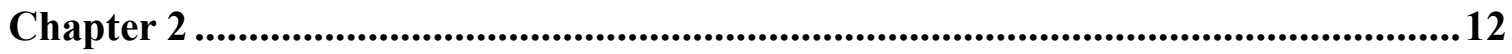

INTRODUCTION .....................................................................................................12

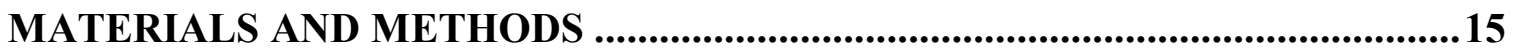

Site description...............................................................................................................15

Benthic macroinvertebrate sampling .........................................................................15

Lab toxicity tests.................................................................................................................16

Multispecies toxicity tests ..................................................................................17

Heptageniidae toxicity tests.............................................................................................19

Data analysis.................................................................................................................20

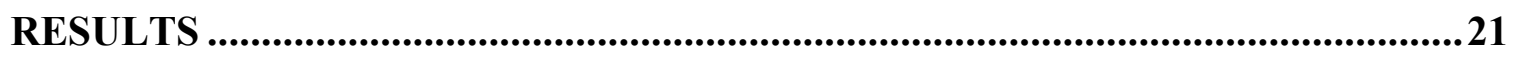

Benthic macroinvertebrate sampling ..........................................................................21

Laboratory toxicity tests ...................................................................................................21

Multispecies toxicity tests .........................................................................................22

Heptageniidae toxicity test ...............................................................................................23

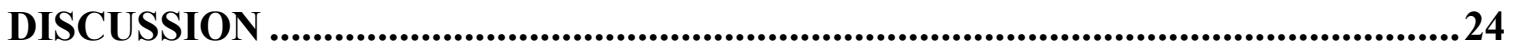


Receiving stream invertebrate community ............................................................24

Nutrient effects on macroinvertebrates .............................................................25

Mechanisms of toxicity .........................................................................27

Overall effects of trout effluents ..........................................................................28

Assessment of methods in this study .......................................................29

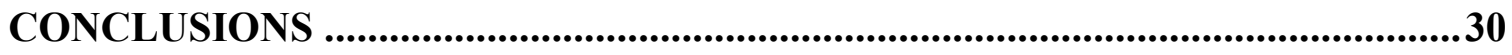

Figure 1 ...............................................................................................................3 32

Figure 2 .......................................................................................................33

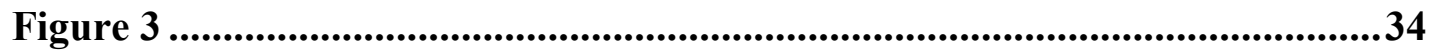

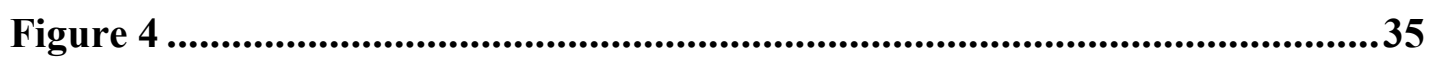

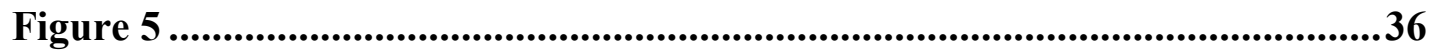

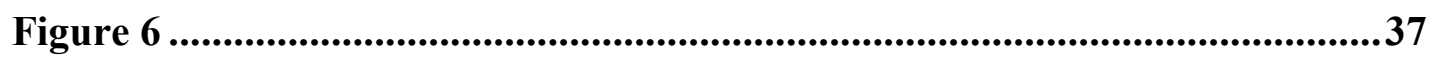

Figure 7 ..................................................................................................................38

Figure 8 .....................................................................................................39

Table 1 ...................................................................................................40

Table 2

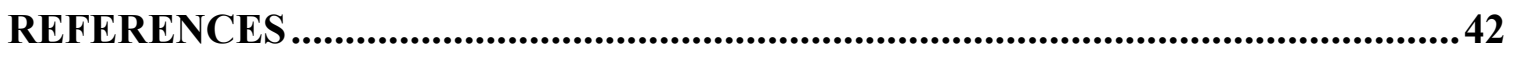

Appendix A: Literature Review References..............................................................45

Appendix B: Figures and Tables Legend ........................................................50

Appendix C: Figures and Tables ............................................................................5

Figure 3.1 ............................................................................................53

Figure 3.2 .................................................................................................54

Figure 3.3 .........................................................................................................55 


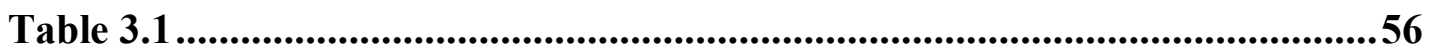

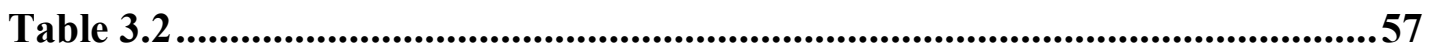

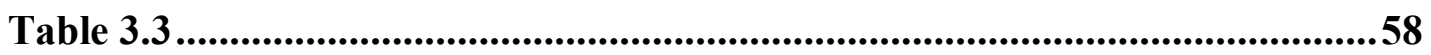

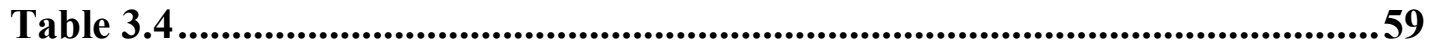

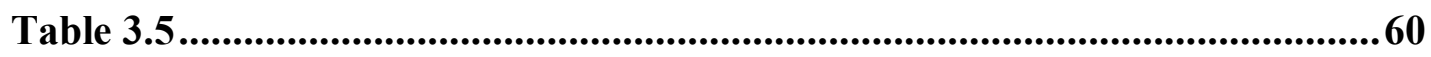

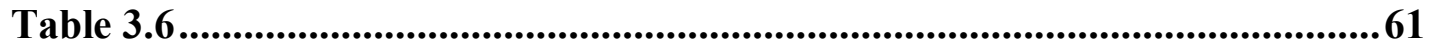

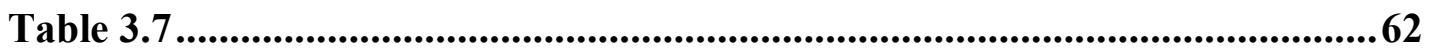

Table 3.8 .......................................................................................................6

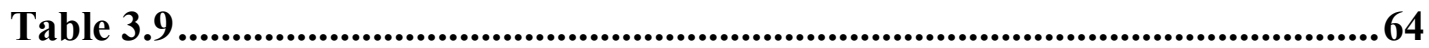

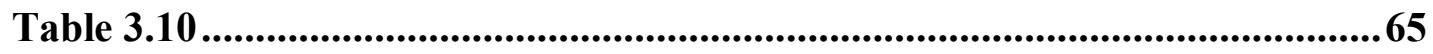

Table 3.11 ...........................................................................................................66

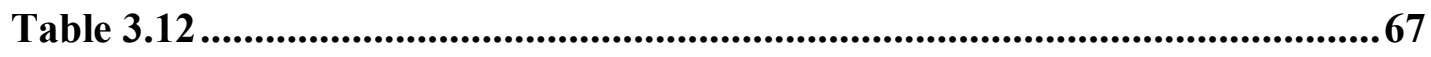

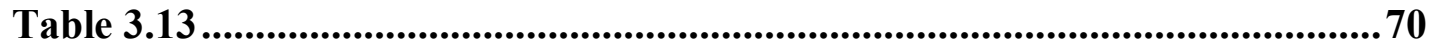

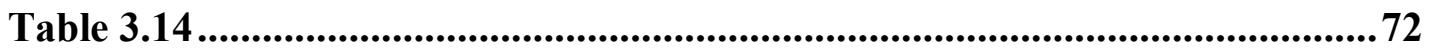

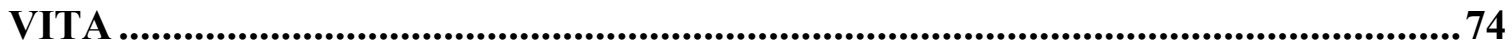




\section{Chapter I: Literature Review}

\subsection{Background}

The effects of rainbow trout aquacultural effluents on the aquatic environment, particularly macroinvertebrates, have not generated a lot of attention in the past in North America (Stephens and Farris 2004). Receiving streams of aquaculture effluent dilute a wide range of pollutants, such as nutrients and suspended solids, but few studies on streams below fish farms document effects in the biotic community. The impetus for studying freshwater biotic effects has come from the 1972 Federal Water Pollution Control Act, specifically the National Pollutant Discharge Elimination System (Selong and Helfrich 1998). Additionally, states now have the power to issue Total Maximum Daily Loads (TMDLs) in aquaculture discharge permits (Maillard 1998). TMDLs can be written based on whether a stream is meeting its aquatic life usage. Macroinvertebrates are the dominant aquatic biota in lotic systems (Merrit and Cummins 1996), and are a good indicator of the ecosystem's health because of their relatively small migration patterns (Fries and Bowles 2002). All studies of the effects of aquaculture on macroinvertebrates have involved the basic design of sampling the community upstream and downstream of the fish farm in question, and none have used toxicity tests with benthic macroinvertebrates. 


\subsection{Trout Farm Pollutants}

Aquaculture's pollutants come mainly from uneaten food, fecal matter, and soluble metabolites (Kendra 1991). The effluent can increase nitrogen and phosphorus concentrations, dissolved oxygen demand, temperature, bacterial concentrations, alkalinity, hardness, and organic and inorganic solids. Variables that affect the amount of pollution from a farm include the culture species, diet, temperature, and management practices of the farmer. The nutrient waste from aquaculture is either released in the form of sludge or as the effluent waste fraction; the majority in rainbow trout farms is discharged in the latter (Axler et al. 1997).

Nitrogen, particularly in the form of ammonia $\left(\mathrm{NH}_{3}\right)$, is one of the most common characteristics of aquaculture effluents. Ammonia is toxic to stream biota and nitrogenous waste in general can lead to an acceleration in algae and plant growth (Boaventura et al. 1997). Several studies in Europe and North America have quantified the nitrogen loadings from salmonid hatcheries. Measured forms of nitrogen are nitrate $\left(\mathrm{NO}_{3}-\mathrm{N}\right)$, nitrite $\left(\mathrm{NO}_{2}-\mathrm{N}\right)$, ammonia, total kjeldahl nitrogen $(\mathrm{TKN}=$ ammonia + organic nitrogen), and total nitrogen (TN). In raceway salmonid farms, nitrate and nitrite loadings are not a significant problem. Two rainbow trout farms in Minnesota recorded no net increase in $\mathrm{NO}_{3}-\mathrm{N}$ between the groundwater-fed influent to the raceways and the effluent (Axler et al. 1997). A land-based trout farm in Europe with open water circulation was found to not contribute to nitrate and nitrite concentrations in the receiving stream. One reason these trout farms do not discharge large quantities of 
nitrate + nitrite is because of the short retention times, which do not allow for nitrification (Rennert 1994). Another cause, which can actually lead to a net decrease in nitrate + nitrite concentrations between the influent and effluent, is photosynthetic activity within the hatchery, which results in uptake of the nutrients (Kendra 1991). However, uneaten food, feces, and excretion across the surface of fish's gills can lead to a significant ammonia release from aquaculture. The amount of ammonia pollution varies with different hatcheries from an insignificant amount to as high as a $1.46 \mathrm{mg} / \mathrm{L}$ increase at a rainbow trout farm in Portugal (Boaventura et al. 1997). The ammonia variation is probably most attributable to the amount of feed given and the time of day measurements are taken, as there can be an increase in ammonia discharge directly after feeding (Rennert 1994).

The other nutrient common in aquaculture effluents is phosphorus, in the particulate form or the dissolved form. While particulate phosphorus accumulates as sludge in the basins or near the outfall of the fish farm, the soluble form directly affects water quality and can lead to eutrophic conditions (Rennert 1994). The particulate form can range from 7-64\% in aquaculture (Garcia-Ruiz and Hall 1996), and rainbow trout raceways in Portugal were reported to release a particulate phosphorus to total phosphorus ratio of 0.3 (Boaventura et al. 1997). As the main sources of pollution from aquaculture are in the fish waste and uneaten food, the phosphorus content of these products is important. Settleable rainbow trout waste typically has similar nutrient concentrations to other animal manures, with a range of phosphorus content of $0.56-4.67 \%$ in an Ontario trout farm (Naylor et al. 1999). Garcia-Ruiz and Hall (1996) found hatchery reared rainbow trout to produce fecal 
material with a phosphorus concentration of $8.25 \mathrm{mg} \mathrm{P} / \mathrm{g}$ dry weight, while the food contained $16.06 \mathrm{mg} \mathrm{P} / \mathrm{g}$ dry weight. The loss was because of a decrease in calciumbound phosphate.

Regulatory agencies commonly restrict suspended solids concentrations in the effluent of aquaculture (Naylor et al. 1999). The concentration of suspended solids is often related to the activity and quantity of the fish and the amount of feed administered. Daily variations in TSS are common, with peaks probably related to the increased excretion of fish at certain times or increased movement of fish when humans walk by (Axler et al. 1997, Rennert 1994). Also, suspended solids increase immensely in the effluent during raceway cleaning. Overall, TSS concentrations vary in several studies of salmonid raceways in the United States between 0 and $35 \mathrm{mg} / \mathrm{L}$ or $0.118-23.8 \mathrm{~g} / \mathrm{kg}$ fish per day (Hinshaw and Fornshell 2002).

Problems with oxygen-depletion tend to be site-specific, with some farms having significant losses of oxygen directly after the outfall and others not, mainly because of replenishment from photosynthesis and aerators (Kendra 1991). Because of the organic pollution from aquaculture raceways, biochemical oxygen demand (BOD) is normally measured, rather than chemical oxygen demand (COD) (Hinshaw and Fornshell 2002). Boaventura et al. (1997) found mean daily $\mathrm{BOD}_{5}$ to range from 353 to $1510 \mathrm{~g} / \mathrm{t}$ of fish in trout farms in Portugal. Like other aquaculture pollutants, oxygen-demand is highest when cleaning takes place. BOD can be related to effluent suspended solids with the relationship: 
$\mathrm{BOD}=0.132(\mathrm{SS})+1.47$ (Hinshaw and Fornshell 2002).

The net change between influent and effluent concentrations of COD in a Washington salmonid raceway was $4 \mathrm{mg} / \mathrm{L}$ (Kendra 1991), similar to the findings at a German trout raceway, with a mean increase of $4.2 \mathrm{mg} / \mathrm{L}$ (Rennert 1994).

The previously mentioned pollutants are the ones most commonly associated with aquaculture effluent. A few other chemical and biological effects from raceway outfalls have been reported. Boaventura et al. (1997) detected increases in total hardness and conductivity in one of three trout farms, and increased numbers of mesophilic bacteria in all three. Another potential effect, not as commonly reported and not related to effluent quality, is the possibility of escaped fish. They can have effects on the receiving stream, such as predation and habitat alteration (Myrick 2002).

\subsection{Trout Farm Effects on Macroinvertebrates}

Immediately following the outfall of a trout farm, the effects on the macroinvertebrate community are generally obvious, with pollution-tolerant worms often dominating the stream bottom. Farther downstream, biological monitoring is more effective at assessing the effects of freshwater pollution, including aquaculture effluent, than physicochemical monitoring (Camargo 1994). It is thought that benthic macroinvertebrates are more sensitive to salmonid aquaculture effluent than fisheries (Camargo 1992); pristine streams are more vulnerable because oligotrophic waters are easily affected by organic enrichment (Kendra 1991). The downstream effects of trout farm effluent on 
macroinvertebrates vary in distance and magnitude from site to site, but the usual observations are an increase in pollution-tolerant taxa directly after the outfall, a decrease in pollution-sensitive taxa and total species richness, and a shift in dominant functional feeding groups.

Several common habitat and food generalist taxa are often reported in the literature as being abundant directly below outfalls of fish farms. These taxa tend to be noninsect species or insects of the order Diptera that are known to be tolerant of organic pollution. The difference in their densities upstream and downstream of trout effluents is usually obvious. Below a Spanish trout farm, a large contribution of invertebrate abundance was from two dipteran families, chironomids and simuliids, and oligochaetes (Camargo 1992). A similar concentration of oligochaetes was found below salmonid hatcheries in Washington, in addition to leeches and physid and planorbid snails (Kendra 1991). Other noninsect taxa common in trout effluents are isopods and gastropods. The relative contribution of noninsects to the total macroinvertebrate community in two Virginia trout farms increased from less than five percent upstream to over 30 percent directly below the outfall (Selong and Helfrich 1998). A third trout farm caused an increase from six percent to 66 percent (Selong and Helfrich 1998). Most of the increase in noninsect taxa was attributable to isopods and gastropods (Selong and Helfrich 1998). Three commercial trout farms in North Carolina were found to have similar results as other studies, with increases in chironomids, simuliids, oligochaetes, and bivalves, Pisidium (Loch et al. 1996). A study in Scotland of salmonid farms where decreases in pollution- 
intolerant taxa did not often occur, still revealed an increased abundance of oligochaete worms (Doughty and McPhail 1995).

Several specific taxa of benthic macroinvertebrates are consistently reduced or missing in the receiving streams of trout aquaculture. With a few exceptions, mayflies (Ephemeroptera), stoneflies (Plecoptera), and caddisflies (Trichoptera) have often been adversely affected by fish farms. The Trichoptera family Hydropsychidae is considered to be pollution-tolerant, except for the taxa Arctopsyche, Parapsyche, and Diplectrona modesta (Loch et al. 1996). Similarly, baetid mayflies are another exception, being tolerant to moderate amounts of organic enrichment and silt (Selong and Helfrich, 1998). Nonetheless, EPT taxa richness and abundance are effective measures of stream quality and are usually decreased below trout farms. Generally in the literature, for hundreds of meters after a trout outfall, EPT taxa are reduced and gradually recover farther downstream. The distance to downstream recovery varies: Kendra (1991) found EPT taxa depression until $0.5 \mathrm{~km}$ after hatchery effluents, while Loch (1996) reported only a partial recovery $1.5 \mathrm{~km}$ after three trout farms in North Carolina. Other specific taxa besides EPT have been reported to be sensitive to aquaculture effluents. Camargo (1992) found the orders Amphipoda and Tricladida, in addition to Plecoptera, to be the most adversely affected by trout farm effluent.

Aquatic insects can be classified by the means in which they obtain their food source as shredders, collector-gatherers, collector-filterers, scrapers, macrophyte piercers, predators, or parasites (Merritt and Cummins 1996). A few times in the literature a shift 
in these functional feeding groups has been recorded below trout farm effluents.

Receiving streams in North Carolina had an increase in collectors compared to upstream reference sites; presumably because they benefit from increased fine organic matter. Directly after the outfall, scrapers were significantly reduced (Loch et al. 1996). In addition to benefiting collectors and depressing scraper numbers, trout effluent can also increase predators and decrease shredders (Camargo 1992). Other types of aquaculture can cause similar results; the macroinvertebrate community downstream of a sportfish hatchery was dominated by collector-gatherers (Fries and Bowles 2002).

Determining the exact cause of the observed changes to the macroinvertebrate community following trout farms is difficult to pinpoint. Dissolved oxygen is usually above any level where stress could occur (Selong and Helfrich 1998, Loch et al. 1996, Kendra 1991). However, anaerobic conditions could exist in microhabitats just below the outfall (Loch et al. 1996). Ammonia concentrations in the effluent are usually below acute lethal levels for stream biota, but can sometimes be higher, especially after feeding (Kendra 1991). Chronic effects of low ammonia concentrations in trout effluent have not been studied. Close to the outfall, substrate embeddedness, caused by settleable solids, has been implicated as a possible stressor. It reduces the habitat quality of aquatic insects by filling interstitial spaces in the benthos (Selong and Helfrich 1998). Brown (1996) reported similar findings, implicating suspended particulate organic matter as the most critical stressor to macroinvertebrates because it eventually settles and deprives organisms of their refuge and impairs the ability of organisms to attach or feed. 


\subsection{Methods for Assessing Pollution on Macroinvertebrates}

Two broad methods have been used to assess the effect of freshwater pollution on macroinvertebrates: laboratory toxicity studies and field biological monitoring. Laboratory toxicity tests usually involve a standard test organism, while biological monitoring generally involves comparing an affected reach of a stream to a reference reach.

The amphipod, Hyalella azteca, is most commonly used for sediment toxicity tests, but has also been used in water-only tests with select chemicals (USEPA 2000). They are highly sensitive to toxins, widely distributed in North America, and easy to culture (Nuutinen et al. 2003). Laboratory tests with $H$. azteca range from several days (Landrum et al. 2005) to many weeks (Borgmann et al. 1989). The standard method for measuring sediment-associated contaminants calls for yeast, Cerophyl ${ }^{\circledR}$, and trout chow (YCT) as the food source for H. azteca (USEPA 2000), but other food sources have been used in some studies, such as Tetra-Min fish food flakes (Borgmann 1994). EPA recommends a photoperiod of $16 \mathrm{~L}: 8 \mathrm{D}$, the water temperature at $23^{\circ} \mathrm{C}$, and a $300 \mathrm{~mL}$ beaker test chamber with 10 organisms in each beaker. Endpoints generally measured are mortality, growth, and reproduction (USEPA 2000).

Biological monitoring, or biomonitoring, can be important because it shows effects that may not be detected with physicochemical monitoring (Camargo 1994). Biomonitoring can be divided into two major types: surveillance and compliance. Surveillance, the 
more common practice of the two, involves surveying before and after a project or upstream and downstream of a pollution source. Compliance is a type of biomonitoring used to make certain water quality standards are met and maintained (Rosenberg and Resh 1993).

Field experiments using artificial substrates are sometimes used to assess pollution effects on macroinvertebrates. They include rock-filled trays, tiles, and multiplate samplers. The main reasons artificial substrates are employed are that they are inexpensive, and easy to use and standardize (Duxbury 2003). Introduced substrates are generally less variable than natural substrate samplers, and rock-filled trays have been reported to be less variable than multiplate samplers. Rock-tray colonization by macroinvertebrates reaches equilibrium after 2-3 weeks (Clements et al. 1989). Experiments using rock-trays have been conducted using artificial streams (Pontasch and Cairns 1989, Courtney and Clements 1998) and to study effluents (Clements et al. 1989). Biomonitoring studies of a coal-fired power plant required only three samples per station to detect highly significant differences in macroinvertebrate density, taxa richness, and abundance of several dominant taxa upstream and downstream of the point source (Clements et al. 1989).

Artificial streams can provide a link between laboratory and field conditions and include recirculating systems, flow-through channels, and dug channels that divert stream water. Open, outdoor channels are the most reliable models, while artificially dug channels represent the most realistic models (Shriner and Gregory 1984). The use of artificial 
streams to study macroinvertebrates has been conducted with both previously colonized substrates (Pontasch and Cairns 1989, Pontasch and Cairns 1991, Kiffney and Clements 1996, Courtney and Clements 1998, Duxbury 2003) and single-species tests with mayflies (Hatakeyama et al. 1997, Hose et al. 2003).

Single species tests using sensitive benthic macroinvertebrates, such as mayflies, are less common than toxicity tests with standardized test organisms, but can hold important advantages when studying a stream inhabited by these animals. The main reasons they are not used as frequently are because of the difficulty in collection and rearing (Diamond et al. 1992). However, toxicity tests using mayflies have been conducted successfully in the past (Diamond et al. 1992, Hatakeyama et al. 1997, Bartsch et al. 1999, Hose et al. 2003, Kennedy et al. 2004). Because mayflies are very fragile, collection of the organisms for study is a very important process. Kennedy et al. (2004) used D-frame dip-nets with flat, 800 X $900 \mu \mathrm{m}$ mesh backs to avoid injury to the mayflies, while Bartsch et al. (1999) collected them with a standard ponar grab. Aeration is often used during transport to the laboratory or field exposure setups. Mortality during this period is generally low (Hatakeyama et al. 1997). Exposure length can range from 12 hours (Hose et al. 2003) to 21 days (Bartsch et al. 1999), and commonly measured endpoints are survival, growth, or molting frequency. 


\title{
Chapter 2 BENTHIC MACROINVERTEBRATE SUSCEPTIBILITY TO TROUT FARM EFFLUENTS
}

\author{
Lenn Roberts, $\uparrow$ Gregory Boardman, $\dagger$ and Reese Voshell $\uparrow$ \\ $\dagger$ Department of Civil and Environmental Engineering, Virginia Tech, Blacksburg, VA, USA \\ ftDepartment of Entomology, Virginia Tech, Blacksburg, VA, USA
}

\begin{abstract}
The direct effects of a Virginia trout farm on benthic macroinvertebrates were examined using multiple approaches. Static laboratory tests with the amphipod, Hyallela azteca, were conducted with exposures to water taken from a spring, effluent above a sedimentation basin, and effluent below a sedimentation basin. On-site mesocosms were constructed to expose previously colonized artificial substrates to the same treatments as the laboratory tests. Flat-headed mayflies were also collected from a nearby stream and transported to the mesocosms for a 10 day exposure. There was no significant difference between treatments in the laboratory tests after 20 days, but after 28 days the control was significantly lower than the above sedimentation basin treatment in one test. In the multispecies field tests, a clear decrease in total invertebrate abundance and EPT abundance was seen in the effluent treatments compared to the spring water treatments, with a slight improvement in survival in the treatment below the sedimentation basin. However, only total invertebrate abundance after 21 days produced statistically significant differences. A significant difference was detected between the effluent and the spring treatments in the flat-headed mayfly field test. We suggest that the effects seen in this study do not explain the lack of taxa richness in the receiving stream. The main cause of mortality from trout effluents appears to be solids accumulating upon the organisms, and sedimentation basins should be effective best management practices for protecting macroinvertebrates.
\end{abstract}

Keywords-trout effluents benthic macroinvertebrates artificial substrates Hyallela

\section{INTRODUCTION}

Rainbow trout aquaculture in Virginia is a burgeoning industry with obvious benefits, but it also is a cause for concern to State natural resource agencies. The Virginia Department of Environmental Quality (VDEQ) issues permits to coldwater fish farms based on flow and receiving stream water quality [1]. The 1972 Clean Water Act also requires a total maximum daily load (TMDL), which includes a point source wasteload allocation (WLA) and nonpoint source load allocation (LA), for impaired streams not meeting their designated uses. 
The most important pollutants originating from trout farms come from residual food and fecal materials [2-4]. Fish manure has similar macronutrient and metal concentrations to other animal manures [5]. These organic solids are discharged as dissolved nutrients or suspended solids [3] and increase phosphorus and nitrogen levels in the receiving stream, potentially causing downstream eutrophication. Increases in ammonia and decreases in dissolved oxygen concentrations have been reported downstream, although usually below toxic levels [1]. Settleable solids are also persistent from trout farms, which can blanket the streambed below the outfall and increase substrate embeddedness [1, 3].

Macroinvertebrate communities below trout farm effluents typically contain reduced numbers of intolerant Ephemeroptera, Plecoptera, and Trichoptera taxa $[1,3,4]$ and increased abundance of invertebrates tolerant to organic enrichment, such as Oligochaeta, Gastropoda, and Isopoda taxa [1,3]. Shredder and scraper functional feeding groups decrease relative to upstream reaches, while the collector-gatherers' proportion increases [6]. Downstream macroinvertebrate communities in receiving streams of trout effluents often show a partial recovery at 400 to 1500 meters below the outfall and begin to resemble upstream reaches [1-3], although such a localized effect is not universal [7].

The effects of aquaculture on a receiving stream's macroinvertebrate community have been studied several times in Europe and Africa [2, 7-10] as well as North America [1, 3, 11-13]; only two studies focus on trout farms in the United States. The amphipod, Hyallela azteca, is a standard bioassay invertebrate used for assessing the toxicity of 
contaminated sediments [14]. It has been used to evaluate aquaculture affected sediments [15], but never to assess trout effluent toxicity to invertebrates. Water-only tests using the organism have been conducted using cotton gauze [16] or a screen [17] as a substrate. The present work used H. azteca in chronic laboratory tests with water-only exposures to detect direct toxicity of a trout effluent to the organism.

Multispecies toxicity tests are valuable supplements to standard, single species tests because of their ecosystem level predictions and relatively low cost [18]. Artificial substrates provide a statistically reliable method to collect a representative sample of stream macroinvertebrates and have been employed using rock-filled trays [19], multiplate samplers [20], or tiles [21]. Once colonized, artificial substrates can be transported to experimental setups for multispecies toxicity tests $[18,20,22]$. Field multispecies toxicity tests using previously colonized rock-filled trays from another stream were exposed to spring water and trout effluents in onsite mesocosms.

A final toxicity test using the same mesocosms was conducted to provide additional information. It used flat-headed mayflies (Heptageniidae) collected from nearby streams and transported to the trout facility. A test duration of 7 to 14 days using species from this family is comparable to U.S. Environmental Protection Agency 7-d short-term chronic tests [23]. The overall goal of the three types of toxicity tests performed in the present work was to determine the direct toxicity of trout effluent to benthic macroinvertebrates with the elimination of important confounding variables, such as agricultural runoff. 


\title{
MATERIALS AND METHODS
}

\author{
Site description
}

The trout facility studied is located in western Virginia, and draws water directly from a spring into a series of raceways. The spring water then flows into a sedimentation basin and is discharged into a side stream, which flows through pasture for 0.8 miles until the confluence with a larger stream.

\section{Benthic macroinvertebrate sampling}

Benthic macroinvertebrates were sampled in the stream below the trout farm in June 2005. A $100 \mathrm{~m}$ reach directly above the confluence with the larger stream and a $100 \mathrm{~m}$ reach below the trout farm after the side stream were sampled. Sampling involved a combination of 20 kicks or jabs in each reach using a D-frame net. The net was held against the stream bed and the area 0.5 meters upstream was disturbed to dislodge organisms for kicks, and the net was forcefully thrusted 0.5 meters upstream for jabs. Cobbles located in faster moving riffles and runs comprised most of the samples and submerged vegetation supplied the rest of the stream studied. Each reach was sampled moving upstream. The D-frame net was periodically cleaned into a 5-gallon bucket filled with alcohol to be transported back to the laboratory, where the organisms were sorted and identified. 


\section{Lab toxicity tests}

Two static-renewal chronic toxicity tests using $H$. azteca were conducted with three different treatments: spring water, trout effluent before the sedimentation basin, and trout effluent after the sedimentation basin. Survival after 20 days and 28 days were the endpoints measured in both experiments. Four replicates were used for each treatment for a total of 12 exposure chambers. The exposure chambers consisted of $300 \mathrm{~mL}$ tallform beakers with $200 \mathrm{~mL}$ of sample water. A small $(\sim 1 \mathrm{~cm})$ dried oak leaf was rinsed in distilled water and placed at the bottom of each beaker for a substrate and food supply.

Amphipods were supplied by Chesapeake Cultures, Inc. from Hayes, Virginia. They were shipped overnight in water at $23.5^{\circ}$ Celsius with a $\mathrm{pH}$ of 7.95 . A large leaf was provided in shipment to serve as a substrate. The organisms were approximated to be 7 days old by using an age to size correlation; they ranged from 1.5 to $1.8 \mathrm{~mm}$ in size. Twelve amphipods were placed in each beaker using a pipette.

Test water was collected onsite and stored at $4^{\circ} \mathrm{C}$ until the night before it was to be used, where it was set out in the laboratory to reach room temperature. Water was renewed every four days for each replicate. Ammonia was measured using an Accumet ${ }^{\circledR}$ ammonia ion selective electrode. Initial and final values of ammonia were recorded as $\mathrm{NH}_{3}$ for each water renewal. Hardness and alkalinity were measured by titration for each of the three treatment waters before renewal [24]. Dissolved oxygen and temperature 
were measured using an YSI ${ }^{\circledR}$ DO meter and recorded for each treatment water before renewal, and in each beaker at the end of the four day period before renewal. The $\mathrm{pH}$ was measured using a probe for each treatment water before being used. It was monitored daily in each beaker and adjusted to initial values. Initial values ranged from 7.55 to 7.75 , and the $\mathrm{pH}$ never reached above 8.10 or below 7.50 before daily adjustment.

\section{Multispecies toxicity tests}

In the multispecies field toxicity tests, artificial substrates previously colonized for 1 month were transported to the trout farm and placed in constructed channels. Artificial substrates consisted of $739 \mathrm{~mL}$ plastic trays filled with small cobbles. The trays were square and approximately $5 \mathrm{~cm}$ deep. Two, $2.22 \mathrm{~cm}\left(7 / 8^{\prime \prime}\right)$ holes were drilled into all four sides of the trays to promote colonization and to provide a current through the substrate. Rocks were collected from the dry banks of various streams ahead of placement into the colonizing stream. The artificial substrates were held secure in the colonizing stream with hardware cloth and rebar. One or two trays were wrapped in hardware cloth and then nailed into the stream bed.

The stream used to colonize the trays is about 20 minutes south of the trout farm. It was chosen as the colonizing stream because it had the most diverse community of insects found in the nearby area. It was important to find a stream nearby because of the concern of insects dying during transport to the trout farm. Also, the stream runs adjacent to a road, so access to the trays was easy. The trays were placed just west of an abandoned 
rock quarry where the stream has a large, wooded hill on one side and approximately 20 meters of brush on the other side.

The spring water exposure was the control in the experiment. Because the trout farm draws water straight from the spring into the raceways, there was no upstream reach for the colonized samples to be placed. Therefore, water needed to be pumped from the spring into constructed channels. A Tsurumi ${ }^{\circledR}$ submersible pump was placed in the spring and pumped water into $15.24 \mathrm{~cm}(6 ") \mathrm{PVC}$ pipe which led to three galvanized pipe channels where the samples were placed. All flow was regulated by $5.08 \mathrm{~cm}$ (2") ball valves and an extra valve was used for excess flow. The same mesocosm design was used for the effluent waters (Fig. 1).

After 12 rock-trays were colonized for 1 month in spring 2005, 6 were gently wrapped in mosquito netting and placed in coolers with battery-operated aerators to be transported to the trout farm. Three were placed in the mesocosm below the sedimentation basin and three were placed in the spring water mesocosm. Of the six remaining rock-trays, three were wrapped in mosquito netting and placed back in the colonizing stream, and three were sorted immediately to get an estimate of initial colonization. After a 10 day exposure period, samples were sorted onsite. Invertebrates still alive were placed in alcohol and transported back to the laboratory to be identified.

Twenty-five more rock-trays were placed in the colonizing stream for 1 month from April to May 2005 to provide an additional multispecies toxicity test with all three 
mesocosms (spring, above sedimentation basin, below sedimentation basin) for a longer exposure period. Six trays were placed in each mesocosm, two in each channel. They were separated approximately $25.4 \mathrm{~cm}(10$ ”) with rocks placed before and after the front tray to keep them apart and provide flow heterogeneity. On the day the trays were transferred to the trout farm mesocosms, two trays were immediately sorted and two were wrapped in mosquito netting and placed back in the colonizing stream. After a 15 day exposure period, one sample from each channel was retrieved and sorted onsite, as well as one of the trays from the colonizing stream. Six days later, after an exposure period of 21 days, the rest of the samples were sorted.

\section{Heptageniidae toxicity tests}

Heptageniid mayflies were collected in June 2005 from the same colonizing stream that the rock-trays were located. Cobbles in riffle areas were gently rinsed off, and the mayflies were kept in a cooler with aeration. The mayflies were transported to the same mesocosms from the multispecies toxicity tests and all organisms that were uninjured were used. Four replicates were used for the spring and below sedimentation basin mesocosms with 10 mayflies per replicate. The mayflies were placed in the same trays as used in the multispecies test. A large, flattened rock from the colonizing stream was placed in each tray to provide a substrate and food supply. Like the multispecies test, the trays were wrapped in mosquito netting to prevent drift and emergence. After 10 days, survivors were counted from each sample. 


\section{Data analysis}

For the multispecies toxicity tests, differences in macroinvertebrate abundance and EPT abundance between treatments were analyzed using one-way analysis of variance (ANOVA). To stabilize variances, all data were transformed using a square root transformation. Following the detection of differences between treatments $(p \leq 0.05)$, Tukey's test was used to determine which differences were significant [25].

For the $H$. azteca laboratory tests, values for survival were transformed using an arc sine square root transformation. Normality and homogeneity of variance were tested with Shapiro-Wilk and Bartlett's Test, respectively. If the data were normally distributed and the variances were not different, Dunnett's Procedure was conducted to compare the treatment with the highest proportion surviving to the other two treatments. If the data were not normally distributed or had heterogenous variances, Steel's Many-One Rank Test was performed to compare the treatments [26].

For the Heptageniidae field test, values of survival were transformed using an arc sine square root transformation. If at least $70 \%$ of the observations were within $\pm s$ of the mean, data were regarded as normally distributed. A two-tailed F-test was used to determine if the two treatments had similar variances. The t-test was used to compare the means of the treatments [25]. 


\section{RESULTS}

\section{Benthic macroinvertebrate sampling}

Both the reach directly below the outfall and the reach directly above the confluence with the Middle River had a very high abundance of macroinvertebrates, with most of them non-insect taxa. Almost all invertebrates collected were aquatic sow bugs of the family Asellidae, scavengers that are tolerant of organic enrichment. Flat worms, order Tricladida, were also visibly abundant on the undersides of rocks, but were not easily collected using the D-frame net because they adhere to the substrate. The insects collected were Diptera; no EPT taxa were found at either site.

\section{Laboratory toxicity tests}

The test beakers' ammonia levels did not increase significantly during the 4 days between water renewals for either test, presumably because no food was given in addition to the maple leaves. Ammonia never reached above $0.80 \mathrm{mg} / \mathrm{L}$ (as $\mathrm{NH}_{3}$ ) for any of the treatments. Dissolved oxygen concentrations usually stayed above $6.00 \mathrm{mg} / \mathrm{L}$, with the lowest recorded value of $5.50 \mathrm{mg} / \mathrm{L}$ in the above sedimentation basin water. The second laboratory test was conducted under colder conditions (approximately $4^{\circ} \mathrm{C}$ cooler), but did not affect the survival of the amphipods. Alkalinity and hardness were very high, ranging from 152 to $168 \mathrm{mg} / \mathrm{L}$ as $\mathrm{CaCO}_{3}$ and 177 to $198 \mathrm{mg} / \mathrm{L}$ as $\mathrm{CaCO}_{3}$ for all 
treatments, respectively. The range of values of the physico-chemical parameters measured during both tests is given in Table 1 .

Of the four endpoints measured, percent survival after 20 days and 28 days for both tests, only one showed a significant difference between any two treatments. After 28 days in Test 1 , percent survival was significantly reduced in the spring water treatment as compared to the above sedimentation basin water treatment. Mean percent survivals after 28 days were $12 \%(n=4), 48 \%(n=4)$, and $31 \%(n=4)$ for the spring water, above sedimentation basin water, and below sedimentation basin water treatments, respectively. The significant reduction in amphipod numbers in the spring water beakers was primarily due to a large loss of life between 20 and 24 days. Figures 2 and 3 show the mean percent survival in Tests 1 and 2, respectively.

\section{Multispecies toxicity tests}

In the 10 day multispecies toxicity test, there was only a slight difference between the spring water and below sedimentation basin effluent treatments. The mean number of invertebrates for the spring water and effluent treatments were $65.7(\mathrm{n}=3)$ and $50.0(\mathrm{n}=$ 3), respectively. The spring water mesocosm had a mean EPT abundance of $26.3(n=3)$; and, the effluent mesocosm had a mean EPT abundance of $22.0(n=3)$. Neither of the endpoints measured after 10 days showed significant differences. The test did show the effectiveness of the mesocosms at maintaining the colonized substrates, as the total invertebrate abundance and total EPT abundance in the mesocosm treatments were 
similar to or higher than the samples removed and analyzed during the date of transfer and the samples placed back in the colonizing stream. This was the justification for fewer samples being placed back into the colonizing stream after being wrapped in mosquito netting during the 15 and 21 day tests.

The spring water treatment in the 15 day and 21 day toxicity tests produced the greatest invertebrate and EPT abundance, followed by the below sedimentation basin effluent treatment. The above sedimentation basin treatment had very low invertebrate and EPT abundance after 21 days. However, the only statistically significant difference in all of the multispecies toxicity tests was the difference in total invertebrate abundance after 21 days $(\mathrm{F}=24.141, \mathrm{p}<0.05)$. The spring water and below sedimentation basin treatments had significantly greater invertebrate abundance than the above sedimentation basin treatment. Table 2 provides the mean number of invertebrate and EPT abundance for all of the multispecies tests.

\section{Heptageniidae toxicity test}

Figure 4 shows the mean number of survivors in the Heptageniidae toxicity test, $7.5(\mathrm{n}=$ 4) for the spring water treatment and $4.5(n=4)$ for the below sedimentation basin treatment. The difference in survival between the two was significant $(\mathrm{t}=4.43)$. It was noted that solids from the effluent collected between the legs and gills of the mayflies in the effluent setup (Figure 5) to a greater extent than in the spring water setup (Figure 6). 


\section{DISCUSSION}

\section{Receiving stream invertebrate community}

The results of the sampling indicate a macroinvertebrate community greatly altered by organic enrichment. The diversity in both the reach directly below the outfall and the reach above the confluence was extremely low, and lower than studies of other streams affected by trout effluents [1-3]. For example, no EPT taxa were found in samples from the receiving stream. Loch et al. [3] found EPT taxa richness 20-50 m below outfalls of three North Carolina trout farms greater than 30 during their June sampling. Also, the effects of other fish farms are more localized than the effects of this trout farm $[2,11]$. The macroinvertebrate community below the trout farm studied was clearly more impaired than other receiving streams of trout effluents.

A possible explanation to this discrepancy is that additional variables besides the trout effluent may be degrading the benthic community in the receiving stream. The results of the laboratory and field toxicity tests in our study do not completely explain the extremely low taxa richness in the receiving stream, as many EPT taxa survived in the effluent treatments. McKay [27] notes that local disturbances of streams can be recolonized by organisms upstream. However, the trout farm draws water directly from a groundwater source, so no recolonization is possible from any upstream reach. Several cattle were observed during the summer months in the stream, both in the side stream next to the raceways and farther downstream in the receiving stream. As many as 13 
cows were counted one afternoon approximately 20 meters below the outfall. VADEQ [28] reported total suspended solids of 44.00 and $74.25 \mathrm{mg} / \mathrm{L}$ on two days when cattle were in the side stream. Brown [7] noted that mountain streams in South Africa are minimally affected by trout farm effluents at concentrations of organic particulate matter below $1.5 \mathrm{mg} / \mathrm{L}$. A final confounding variable is the lack of riparian vegetation along the receiving stream, giving it a channel with little to no shade, which could allow increased periphytic productivity during the summer [29]. This open-channel agricultural stream, mostly influenced by autochthonous energy sources, can cause the invertebrate community to have a very high abundance of tolerant groups and a lower abundance of intolerant groups, relative to forested streams [30].

Nutrient effects on macroinvertebrates

Because of the relatively high nitrogen and phosphorus levels of trout effluents, an important goal of this study was to examine invertebrates' responses to elevated nutrients. The laboratory tests with $H$. azteca in this study were most appropriate for assessing the effects of dissolved nutrients in trout effluents. The unionized form of ammonia $\left(\mathrm{NH}_{3}\right)$ is usually accepted as the more toxic form of the pollutant for most organisms, but in softer water $H$. azteca has been reported to be very sensitive to the ionized $\left(\mathrm{NH}_{4}{ }^{+}\right)$form [17]. Therefore, toxicity of ammonia to $H$. azteca is best reported as total ammonia, not just the unionized form. However, because the hardness was so high and the ammonia levels so low in all treatments that the ionized form was not a concern, the values were recorded as unionized ammonia. 
Initial unionized ammonia values for each water renewal were about twice as high in the effluent water treatments than in the spring water treatment, but did not affect the survival of the amphipods. The survivorship was essentially random in the two tests: the spring treatment had the greatest proportion alive after 20 days in Test 2; the above sedimentation basin treatment had the greatest proportion alive after 28 days in Test 1; and, the below sedimentation basin treatment had the greatest proportion alive after 20 days in Test 1 and 28 days in Test 2. These results are consistent with previous studies of the effects of ammonia on $H$. azteca $[16,17]$, since survival of the amphipods should not be affected by levels less than $0.80 \mathrm{mg} / \mathrm{L} \mathrm{NH}_{3}$, the highest level recorded in the experiment. Borgmann [16] reported a 10 week LC50 for 0-1 week old amphipods of $13.09 \mathrm{mg} / \mathrm{L} \mathrm{NH}_{3}$. The highest ammonia value ever reported in the effluent from the TMDL for Cockran Spring Branch was $0.737 \mathrm{mg} / \mathrm{L} \mathrm{NH}_{3}-\mathrm{N}$ [2]. Because of the historically low concentrations and the low concentrations measured during the laboratory tests, it is concluded that the ammonia in the trout effluent did not adversely affect survival of the amphipods.

A certain amount of extrapolation is needed to assess nutrient effects on other macroinvertebrates based upon the data generated from the laboratory tests. A 29-day mesocosm study of chronic ammonia toxicity revealed that a genus in the mayfly family, Leptophlebiidae, was the most sensitive invertebrate, with an $\mathrm{EC}_{50}$ value of $0.145 \mathrm{mg}$ N/L unionized ammonia [31]. However, the multispecies toxicity tests in the present work had many samples that contained numerous individuals of a taxon, 
Paraleptophlebia, in this family, including samples exposed to the trout effluents. In some cases, this genus accounted for the majority of EPT abundance numbers in the effluent treatments.

Phosphorus concentrations were not recorded during this study, but Stewart [32] measured total phosphorus levels of $0.08 \mathrm{mg} / \mathrm{L}$ or less in the trout effluent during the months that the toxicity tests took place. Levels that low are not believed to have contributed to the toxicity to the organisms in the tests. Macroinvertebrates do not directly respond to phosphorus enrichment, but instead respond to changes in dissolved oxygen concentration and habitat alterations that accompany high TP levels [33].

\section{Mechanisms of toxicity}

Because previous studies of trout aquaculture on benthic invertebrates involve sampling of the receiving stream and do not include toxicity tests of the direct effects of the effluent, there is little information on what physico-chemical parameters in the water, if any, are killing the invertebrates. The main causes of reduced macroinvertebrate numbers reported in other studies of trout effluents include increased substrate embeddedness [1] and organic matter blanketing the stream bed and the animals themselves [3]. Very high substrate embeddedness was observed in the side stream directly above the outfall, probably because of solids leaking from the solids holding bin, located adjacently. However, this did not seem to be a problem farther downstream, as sufficient habitat was seen in small riffles and runs. This study produced clear evidence 
that organic growth and particles on the invertebrates were the most likely causes of toxicity. Figures 7 and 8 show the contrast in substrates at the end of the multispecies test; the effluent samples had a thick, green-colored film that grew on the rocks and the invertebrates. Solid fecal and food particles from the fish also collected between the legs and upon the external gills of the organisms in the effluent samples. The contrast in specimens between the control and trout water treatments can be seen in Figures 5 and 6 . This is important to organisms with external gills, such as most EPT taxa, because respiration can be hindered. All of the intact, dead invertebrates found in the field tests were entombed in solids collected on their body parts.

\section{Overall effects of trout effluents}

The trout effluent in the current study consistently resulted in reduced numbers of invertebrates, including EPT taxa, in the field tests. The fact that many of the results were not statistically significant can be explained by the large variability associated with multispecies experiments. A small improvement in survival was also noted in the field work after the effluent flowed through the sedimentation basin. Reducing settleable solids in this manner proves to be an effective addition to trout farm best management practices. Dissolved compounds are not a likely cause of mortality in macroinvertebrates, indicated by similar survivorship between treatments in the laboratory tests. Overall, it is not believed that the trout farm point source at the headwaters of the receiving stream is fully responsible for the absence of EPT taxa. 


\section{Assessment of methods in this study}

For the laboratory tests with $H$. azteca, a substrate such as the maple leaves in this study is very important to keep the invertebrates alive. Earlier attempts with cotton gauze as a substrate and gentle aeration through a pipette produced tests that lasted for 2 weeks or less, with most of the amphipods dying within the first two water renewals. Using a small piece of maple leaf prevented any other necessary addition of food. The amphipods were usually seen attached to the leaf, and after a few days, the leaf clearly was filled with gaps where the invertebrates had consumed it. Extensive aeration is also not recommended because it can entrain the animals at the water surface. Early tests with just slight aeration (approximately 1 bubble per second) caused many live amphipods to get caught in the surface tension of the water. After pipetting a drop of water on them, they swam freely in the water column.

The most important detail of field multispecies tests with macroinvertebrates is to control emergence and drift of the animals. In this study, only several emerging adults were found in the samples after the exposure, but it can still be enough to skew the results. Also, flow-through setups in the field run the risk of a large amount of the insects drifting out of the mesocosm, so a method of capturing these organisms is necessary. In this study, wrapping each sample in mosquito netting and sealing it completely was effective at preventing any drift. However, the nets must be cleaned regularly to avoid clogging due to particles in the effluent and algal growth. More than three replicates are recommended for future multispecies tests. Three replicates were sufficient to show 
obvious differences in total macroinvertebrate abundance and EPT abundance between treatments, but during only one occasion were the differences statistically significant. The duration of the exposure in multispecies tests depends on the contaminant or effluent being studied, but in experiments analyzing chronic effects of a complex effluent such as a trout farm, 20 to 25 days should be sufficient.

Combining different approaches to characterize an effluent can be an effective method at determining the extent of ecological damage. Each method has both important advantages and drawbacks. For example, in the present work, laboratory toxicity tests were static, allowing solids from the trout farm to settle in each beaker. This was necessary to prevent injury to the organisms from intensive recirculation that could have suspended particles, but the static conditions eliminated any potential toxicity due to suspended solids. A necessary supplement was therefore the field mesocosm tests, which allowed exposure to suspended solids, as well as natural environmental factors such as temperature and light. Hose et al. [34] used laboratory, mesocosm, and field tests to examine the effects of endosulfan; and, it is recommended that future studies of complex effluents such as the trout farm in the present study also use a variety of toxicity studies.

\section{CONCLUSIONS}

The results of the field and laboratory evaluations indicate that the trout effluent is moderately toxic to benthic macroinvertebrates, particularly those that dwell in fastermoving currents, have external gills, and are not adapted to life in sediments and detritus. 
Particles accumulating along the surface on individual animals are most likely responsible for direct mortality, and the indirect effects of trout effluents are localized. However, the toxicity observed in this study does not explain the complete absence of sensitive taxa along the entire receiving stream. It is recommended that the sedimentation basin continue to be operated efficiently and solids in the solids holding lagoon are kept sealed to keep all effects of substrate embeddedness within the side stream. 
Figure 1 Photograph of mesocosm setup at above sedimentation basin treatment.

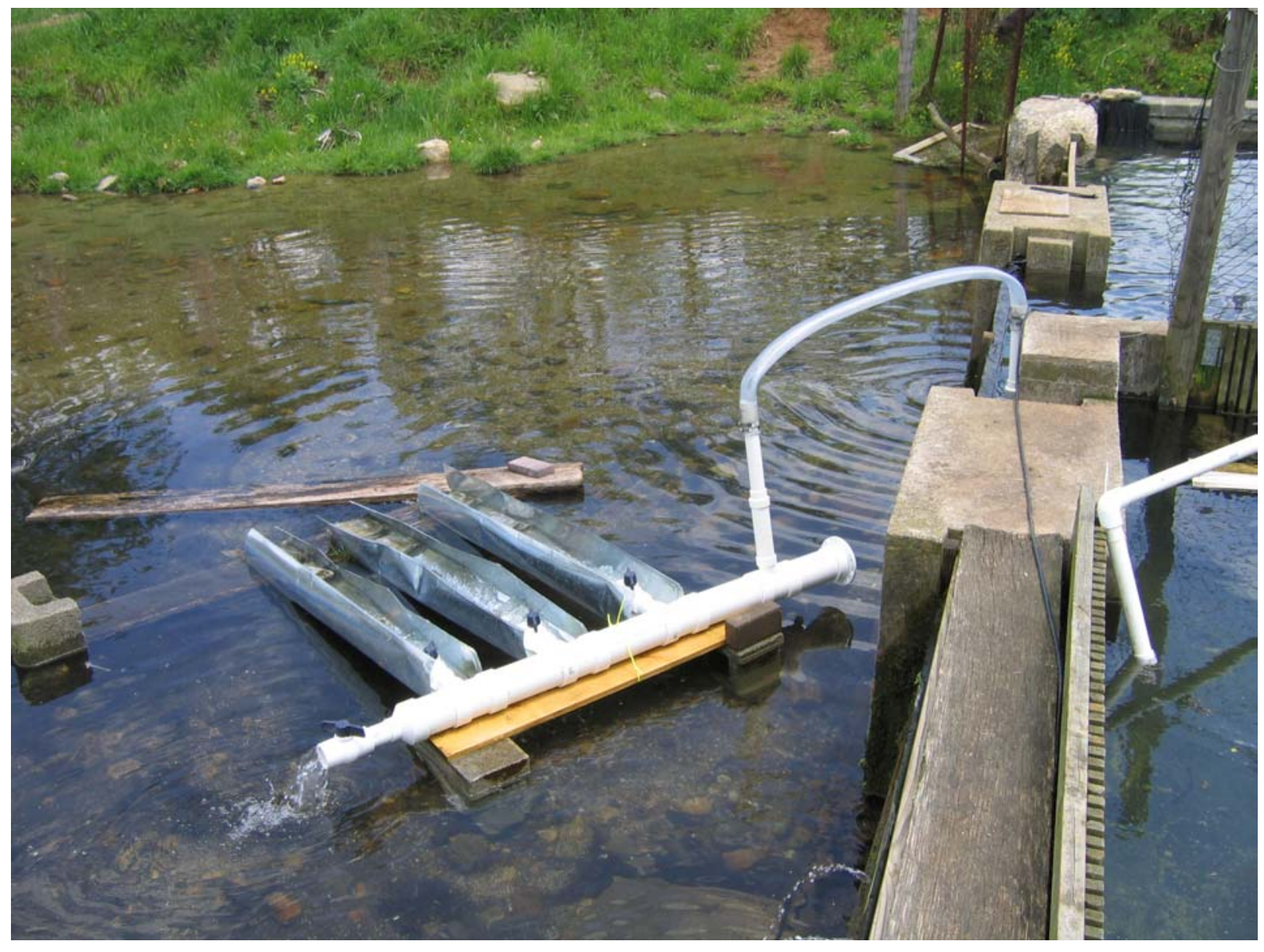


Figure 2 Survivorship of amphipods in Test 1

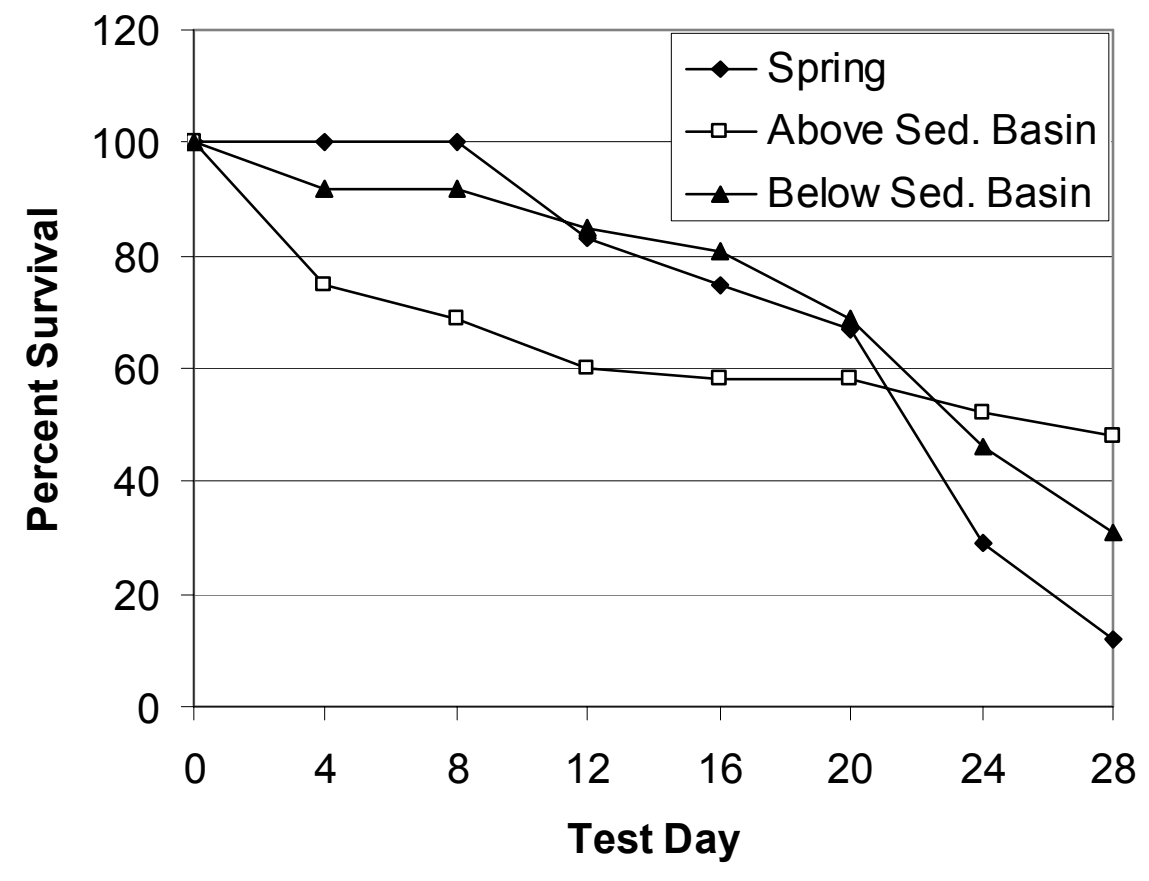


Figure 3 Survivorship of amphipods in Test 2.

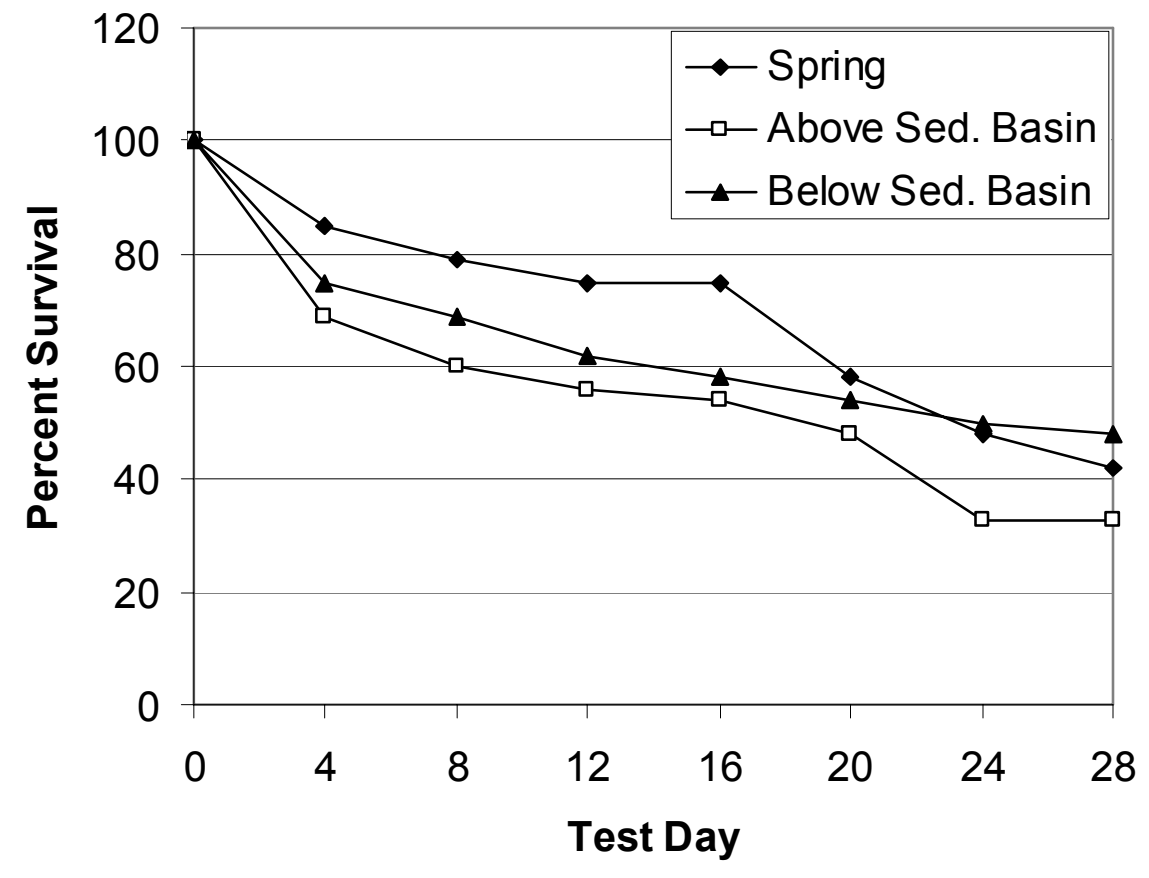


Figure 4 Mean survival of heptageniid mayflies in field mesocosms. Error bars represent \pm 1 standard deviation.

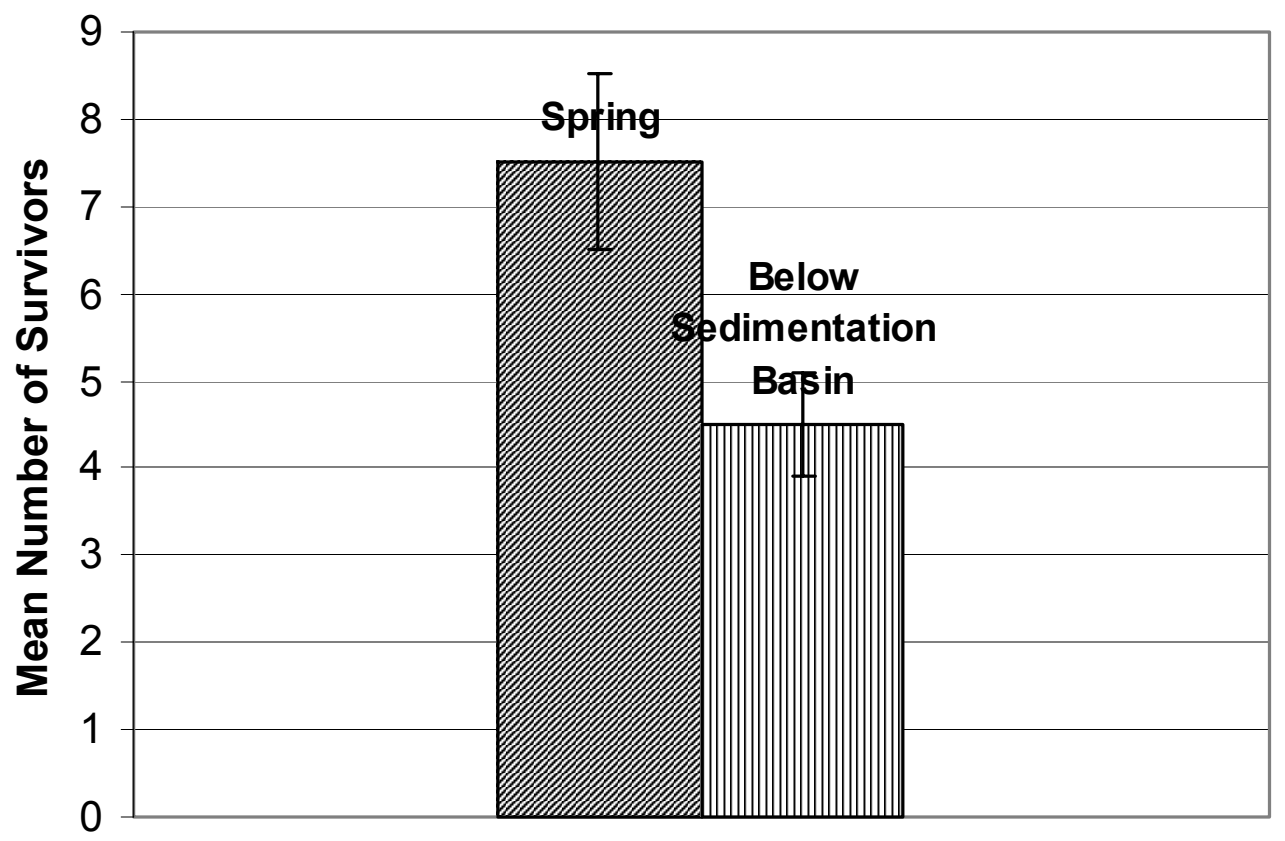


Figure 5 Photograph of heptageniid mayfly from spring water mesocosm after 10 days.

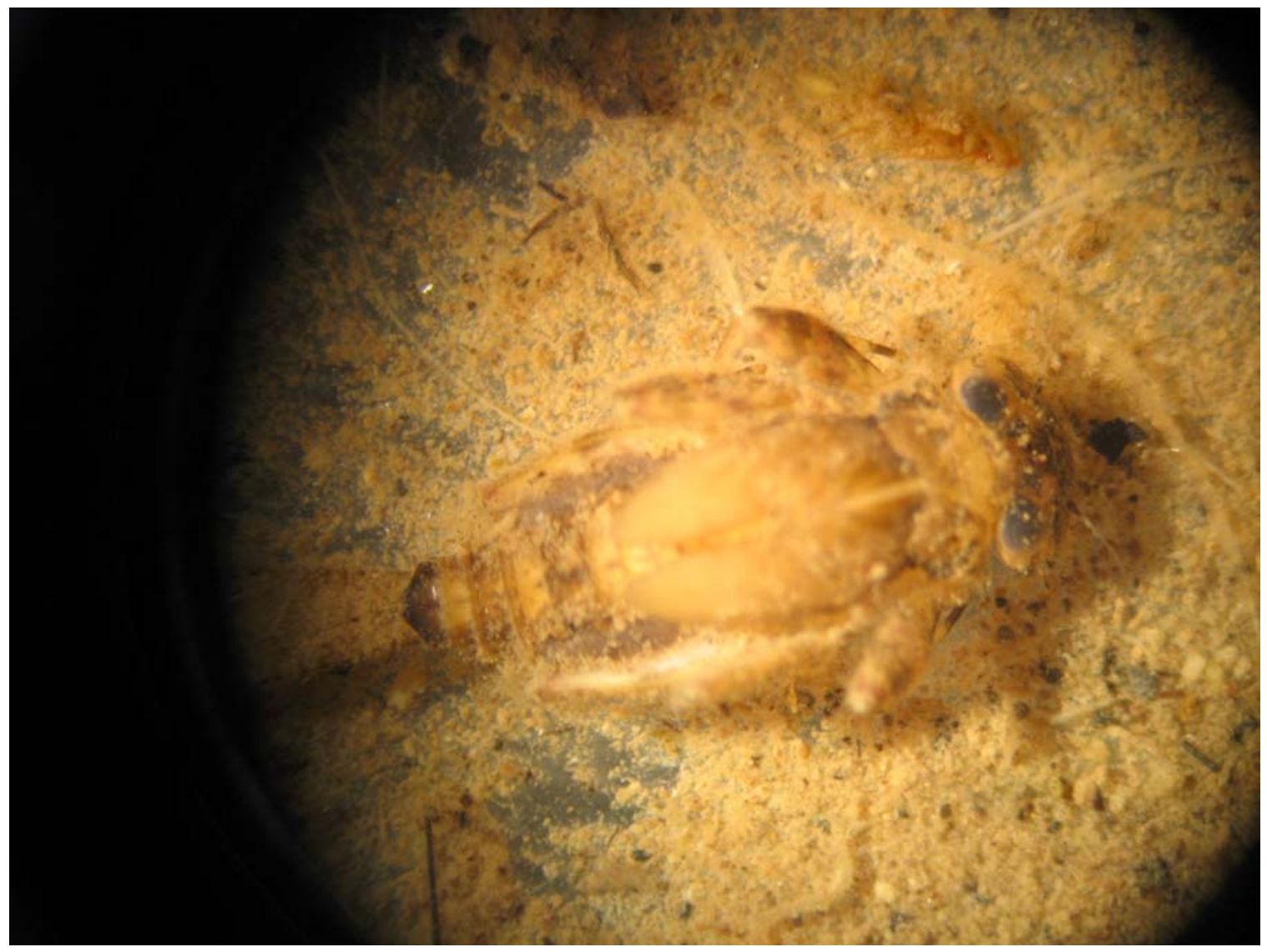


Figure 6 Photograph of heptageniid mayfly from effluent mesocosm after 10 days.

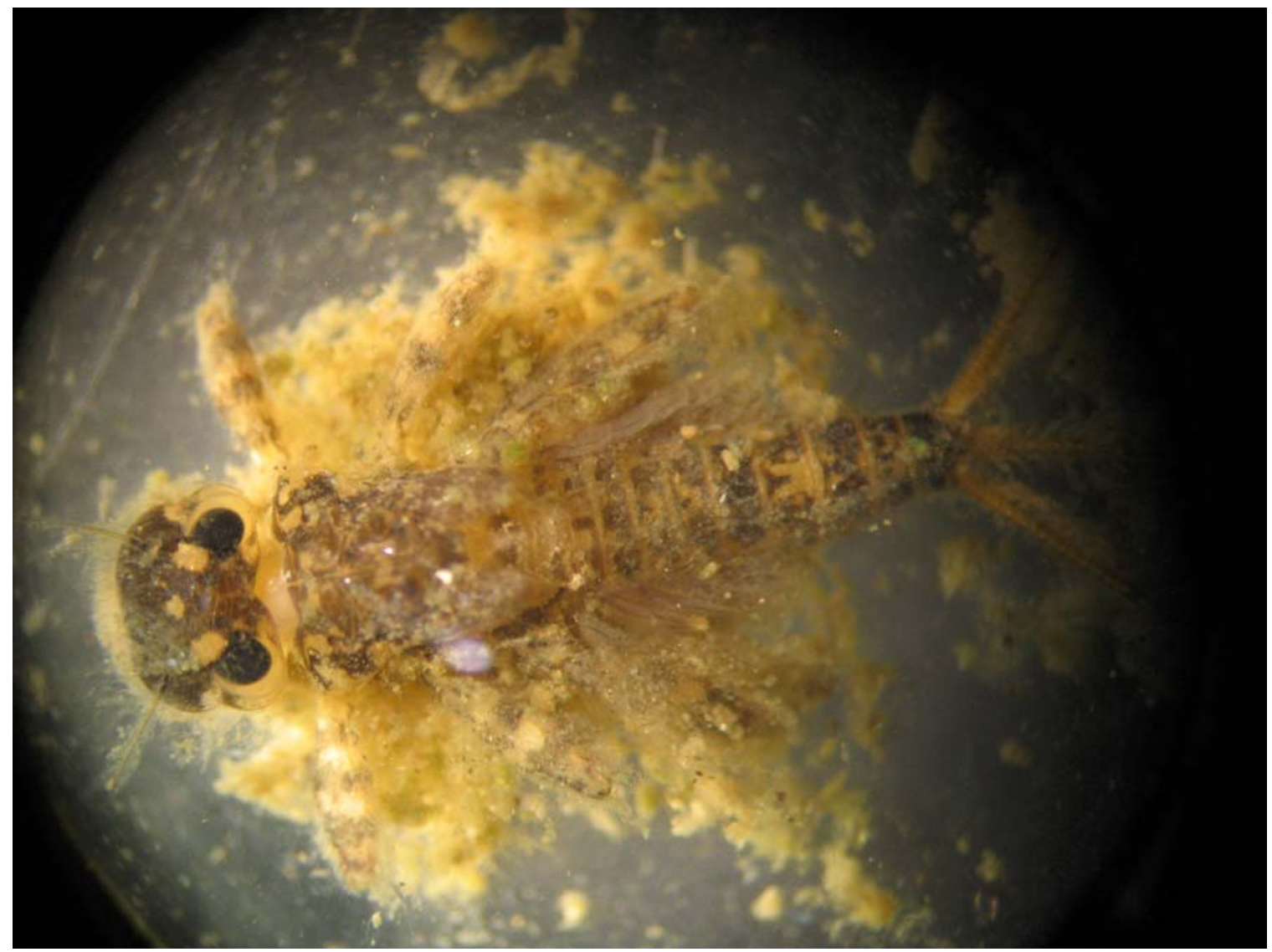


Figure 7 Photograph of spring water treatment artificial substrate after multispecies test.

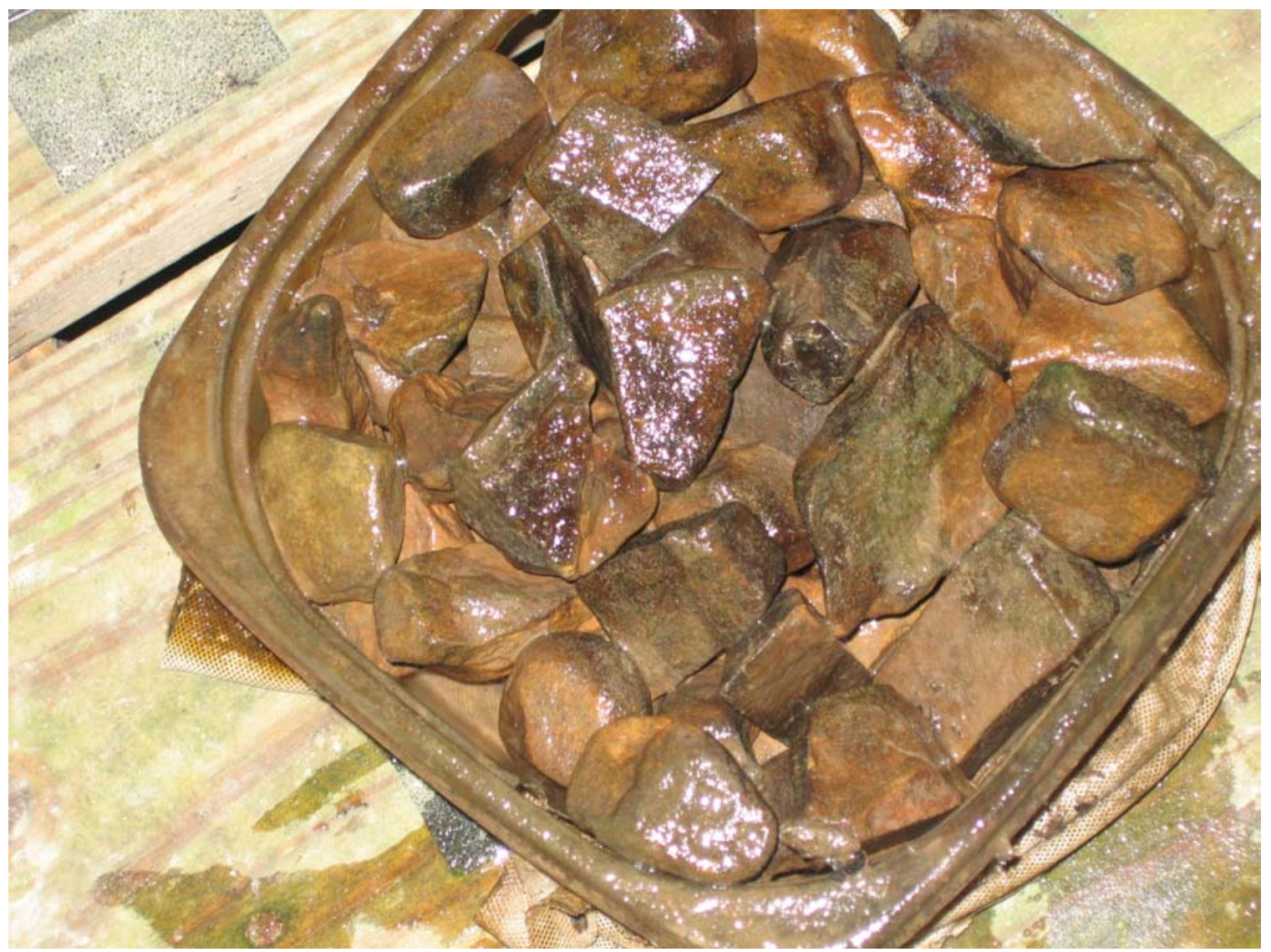


Figure 8 Photograph of organic growth on effluent artificial substrate after multispecies test.

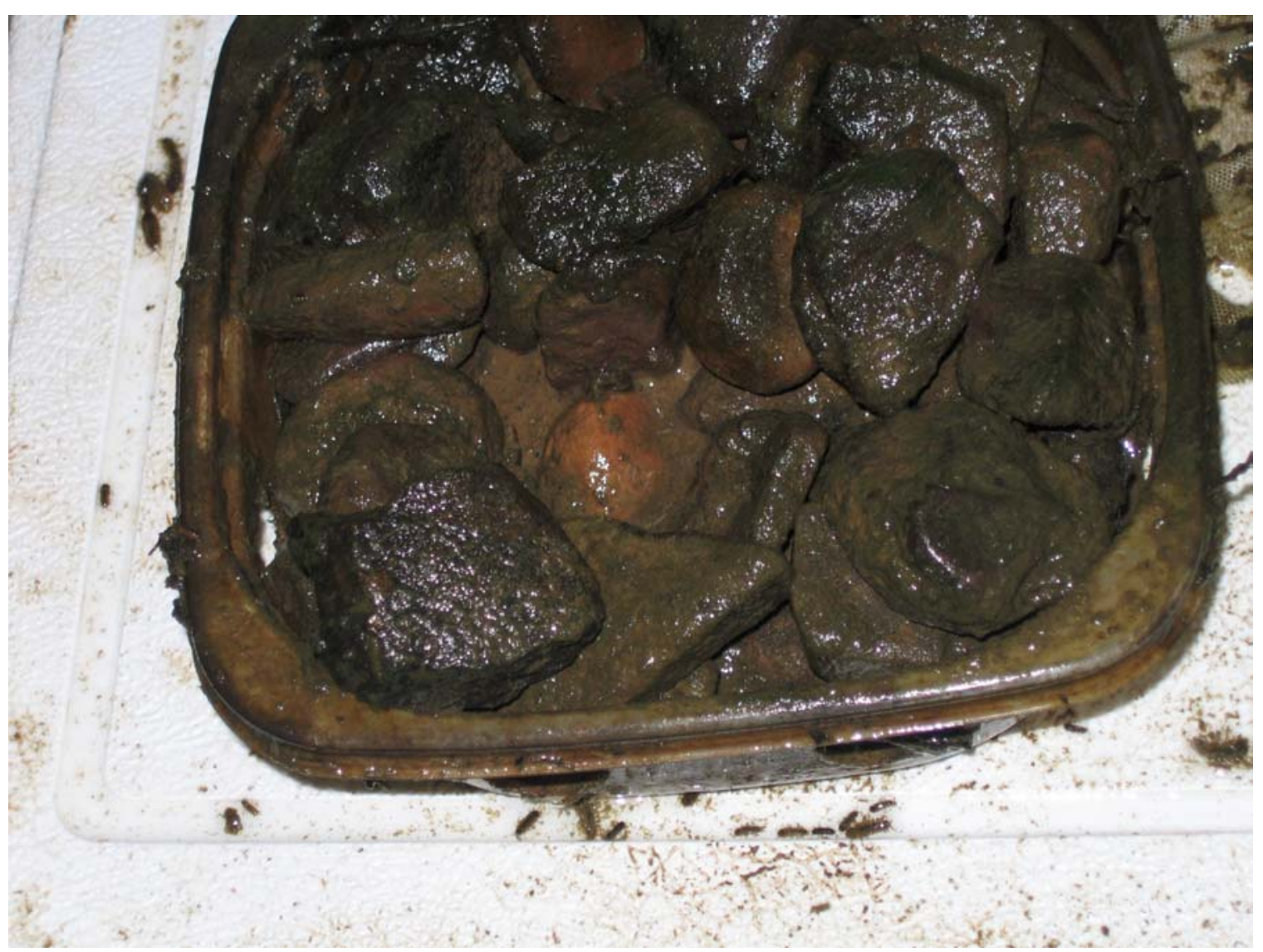


Table 1 Average physico-chemical parameters of laboratory toxicity tests using $H$. azteca. Initial values are measurements of water quality at the beginning of water renewal, while final values are measurements at the end. Ranges are given in parentheses.

\begin{tabular}{|c|c|c|c|c|c|c|}
\hline & \multicolumn{3}{|c|}{ Test 1} & \multicolumn{3}{|c|}{ Test 2} \\
\hline Parameter & Spring & \begin{tabular}{|c|} 
Above \\
Sedimentation \\
Basin
\end{tabular} & \begin{tabular}{|c|} 
Below \\
Sedimentation \\
Basin
\end{tabular} & Spring & $\begin{array}{c}\text { Above } \\
\text { Sedimentation } \\
\text { Basin }\end{array}$ & \begin{tabular}{|c|} 
Below \\
Sedimentation \\
Basin
\end{tabular} \\
\hline $\mathrm{pH}$ & $\begin{array}{l}7.70 \\
(7.63-7.76)\end{array}$ & $\begin{array}{l}7.67 \\
(7.59-7.76)\end{array}$ & $\begin{array}{l}7.68 \\
(7.62-7.76)\end{array}$ & \begin{tabular}{|l|}
7.67 \\
$(7.62-7.70)$
\end{tabular} & $\begin{array}{l}7.62 \\
(7.56-7.72)\end{array}$ & $\begin{array}{l}7.63 \\
(7.55-7.72)\end{array}$ \\
\hline $\begin{array}{l}\text { Hardness } \\
(\mathrm{mg} / \mathrm{L} \text { as } \\
\left.\mathrm{CaCO}_{3}\right)\end{array}$ & $\begin{array}{l}194 \\
(188-198)\end{array}$ & $\begin{array}{l}188 \\
(184-195)\end{array}$ & $\begin{array}{l}188 \\
(183-196)\end{array}$ & $\begin{array}{l}189 \\
(185-194)\end{array}$ & $\begin{array}{l}184 \\
(177-190)\end{array}$ & $\begin{array}{l}184 \\
(178-190)\end{array}$ \\
\hline $\begin{array}{l}\text { Alkalinity } \\
(\mathrm{mg} / \mathrm{L} \text { as } \\
\left.\mathrm{CaCO}_{3}\right)\end{array}$ & $\begin{array}{l}164 \\
(159-168)\end{array}$ & $\begin{array}{l}160 \\
(153-168)\end{array}$ & $\begin{array}{l}160 \\
(156-168)\end{array}$ & $\begin{array}{l}161 \\
(157-167)\end{array}$ & $\begin{array}{l}155 \\
(152-158)\end{array}$ & $\begin{array}{l}154 \\
(151-158)\end{array}$ \\
\hline $\begin{array}{l}\mathrm{T}\left({ }^{\circ} \mathrm{C}\right) \\
\text { Initial }\end{array}$ & $\begin{array}{l}23.3 \\
(22.0-23.9)\end{array}$ & $\begin{array}{l}23.3 \\
(22.1-23.9)\end{array}$ & $\begin{array}{l}23.3 \\
(22.0-23.9)\end{array}$ & $\begin{array}{l}19.7 \\
(18.5-20.5)\end{array}$ & $\begin{array}{l}19.5 \\
(18.5-20.5)\end{array}$ & $\begin{array}{l}19.5 \\
(18.5-20.5)\end{array}$ \\
\hline $\begin{array}{l}\mathrm{T}\left({ }^{\circ} \mathrm{C}\right) \\
\text { Final }\end{array}$ & $\begin{array}{l}23.5 \\
(22.7-24.9)\end{array}$ & $\begin{array}{l}23.6 \\
(22.7-24.9)\end{array}$ & $\begin{array}{l}23.6 \\
(22.7-24.9)\end{array}$ & $\begin{array}{l}19.4 \\
(18.5-19.9)\end{array}$ & $\begin{array}{l}19.3 \\
(18.5-19.6)\end{array}$ & $\begin{array}{l}19.3 \\
(18.5-19.6)\end{array}$ \\
\hline $\begin{array}{l}\mathrm{DO}(\mathrm{mg} / \mathrm{L}) \\
\text { Initial }\end{array}$ & $\begin{array}{l}7.30 \\
(7.05-7.80)\end{array}$ & $\begin{array}{l}6.88 \\
(6.20-7.30)\end{array}$ & $\begin{array}{l}7.10 \\
(6.71-7.60)\end{array}$ & $\begin{array}{l}7.57 \\
(6.40-7.98)\end{array}$ & $\begin{array}{l}6.45 \\
(5.50-7.54)\end{array}$ & $\begin{array}{l}6.94 \\
(6.05-7.62)\end{array}$ \\
\hline $\begin{array}{l}\mathrm{DO}(\mathrm{mg} / \mathrm{L}) \\
\text { Final }\end{array}$ & $\begin{array}{l}7.04 \\
(6.70-7.20)\end{array}$ & $\begin{array}{l}7.03 \\
(6.71-7.17)\end{array}$ & $\begin{array}{l}7.04 \\
(6.68-7.19)\end{array}$ & $\begin{array}{l}7.78 \\
(7.55-7.90)\end{array}$ & $\begin{array}{l}7.72 \\
(7.60-7.85)\end{array}$ & $\begin{array}{l}7.76 \\
(7.51-7.96)\end{array}$ \\
\hline $\begin{array}{l}\text { Ammonia } \\
(\mathrm{mg} / \mathrm{L} \text { as } \\
\left.\mathrm{NH}_{3}\right) \text { Initial }\end{array}$ & $\begin{array}{l}0.16 \\
(0.04-0.26)\end{array}$ & $\begin{array}{l}0.28 \\
(0.17-0.55)\end{array}$ & $\begin{array}{l}0.26 \\
(0.11-0.44)\end{array}$ & $\begin{array}{l}0.19 \\
(0.12-0.28)\end{array}$ & $\begin{array}{l}0.46 \\
(0.28-0.76)\end{array}$ & $\begin{array}{l}0.37 \\
(0.18-0.76)\end{array}$ \\
\hline $\begin{array}{l}\text { Ammonia } \\
(\mathrm{mg} / \mathrm{L} \text { as } \\
\left.\mathrm{NH}_{3}\right) \text { Final }\end{array}$ & $\begin{array}{l}0.24 \\
(0.15-0.41)\end{array}$ & $\begin{array}{l}0.30 \\
(0.21-0.52)\end{array}$ & $\begin{array}{l}0.28 \\
(0.19-0.43)\end{array}$ & $\begin{array}{l}0.26 \\
(0.12-0.47)\end{array}$ & $\begin{array}{l}0.47 \\
(0.28-0.76)\end{array}$ & $\begin{array}{l}0.39 \\
(0.18-0.76)\end{array}$ \\
\hline
\end{tabular}


Table 2 Average invertebrate and EPT abundance of treatments in multispecies toxicity tests. Number of samples is given in parentheses.

\begin{tabular}{|c|c|c|c|c|c|c|}
\hline \multirow{2}{*}{} & \multicolumn{2}{|c|}{ 10 Day Test } & \multicolumn{2}{c|}{ 15 Day Test } & \multicolumn{2}{c|}{ 21 Day Test } \\
\cline { 2 - 7 } & $\begin{array}{c}\text { Avg Invert } \\
\text { Abundance }\end{array}$ & $\begin{array}{c}\text { Avg EPT } \\
\text { Abundance }\end{array}$ & $\begin{array}{c}\text { Avg Invert } \\
\text { Abundance }\end{array}$ & $\begin{array}{c}\text { Avg EPT } \\
\text { Abundance }\end{array}$ & $\begin{array}{c}\text { Avg Invert } \\
\text { Abundance }\end{array}$ & $\begin{array}{c}\text { Avg EPT } \\
\text { Abundance }\end{array}$ \\
\hline Initial & $55.3(3)$ & $17.7(3)$ & $42.5(2)$ & $24.5(2)$ & $42.5(2)$ & $24.5(2)$ \\
\hline Colonizing & $48.7(3)$ & $18.0(3)$ & $44(1)$ & $15(1)$ & $46(1)$ & $18(1)$ \\
\hline Spring & $65.7(3)$ & $26.3(3)$ & $43.7(3)$ & $20.6(3)$ & $31.7(3)$ & $11.7(3)$ \\
\hline A-sed & - & - & $30.7(3)$ & $13.3(3)$ & $13.7(3)$ & $4.0(3)$ \\
\hline B-sed & $50.0(3)$ & $22.0(3)$ & $32.7(3)$ & $15.0(3)$ & $30.0(3)$ & $8.0(3)$ \\
\hline
\end{tabular}




\section{REFERENCES}

1. Selong JH, Helfrich LA. 1998. Impacts of trout culture effluent on water quality and biotic communities in Virginia headwater streams. The Prog Fish-Culturist 60: 247-262.

2. Camargo JA. 1992. Structural and trophic alterations in macrobenthic communities downstream from a fish farm outlet. Hydrobiol 242: 41-49.

3. Loch DD, West JL, Perlmutter DG. 1996. The effect of trout farm effluent on the taxa richness of benthic macroinvertebrates. Aquacul 147: 37-55.

4. Camargo JA. 1992. Temporal and spatial variations in dominance, diversity, and biotic indices along a limestone stream receiving a trout farm effluent. Water, Air, and Soil Pollut 63: 343-359.

5. Naylor SJ, Moccia RD, Durant GM. 1999. The chemical composition of settleable solid fish waste (manure) from commercial rainbow trout farms in Ontario, Canada. N Amer J Aquacul 61: 21-26.

6. Camargo JA. 1994. The importance of biological monitoring for the ecological risk-assessment of freshwater pollution: A case study. Environ Internat 20: 229238.

7. Brown CA. 1996. Macroinvertebrate community patterns in relation to physicochemical parameters measured at two land-based trout farms affecting streams in the South-Western Cape, South Africa. Arch fuer Hydrobiologie 138: 57-76.

8. Boaventura R, Pedro AM, Coimbra J, Lencastre E. 1997. Trout farm effluents: Characterization and impact on the receiving streams. Environ Pollut 95: 379387.

9. Kirkagac MU, Pulatsu S, Koksal G. 2004. Effects of land-based trout farms on the benthic macroinvertebrate community in a Turkish brook. Israeli J Aquacul 56: 59-67.

10. Rennert B. 1994. Water pollution by a land-based trout farm. J Appl Ichthyol 10: 373-378.

11. Kendra W. 1991. Quality of salmonid hatchery effluents during a summer lowflow season. Trans Amer Fisheries Soc 120: 43-51.

12. Fries LT, Bowles DE. 2002. Water quality and macroinvertebrate community structure associated with a sportfish hatchery outfall. N Amer J of Aquacul 64: 257-266.

13. Stephens WW, Farris JL. 2004. Instream community assessment of aquaculture effluents. Aquacul 231: 149-162.

14. U.S. Environmental Protection Agency. 2000. Methods for measuring the toxicity and bioaccumulation of sediment-associated contaminants with freshwater invertebrates. EPA 600/R-99/064.

15. Huggett DB, Schlenk D, Griffin BR. 2001. Toxicity of copper in an oxic stream sediment receiving aquaculture effluent. Chemosphere 44: 361-367.

16. Borgmann U. 1994. Chronic toxicity of ammonia to the amphipod Hyallela azteca; importance of ammonium ion and water hardness. Environ Pollut 86: 329-335. 
17. Ankley GT, Schubauer-Berigan MK, Monson PD. 1995. Influence of $\mathrm{pH}$ and hardness on toxicity of ammonia to the amphipod Hyallela azteca. Can J Fish Aquat Sci 52: 2078-2083.

18. Pontasch KW, Cairns J. 1991. Multispecies toxicity tests using indigenous organisms: Predicting the effects of complex effluents in streams. Arch Environ Contam Toxicol 20: 103-112.

19. Clements WH, Van Hassel JH, Cherry DS, Cairns J. 1989. Colonization, variability, and the use of substratum-filled trays for biomonitoring benthic communities. Hydrobiol 173: 45-53.

20. Duxbury C. 2003. The use of previously colonized multiplate artificial substrates in experimental microcosms. J Fresh Eco 18: 459-464.

21. Lamberti GA, Resh VH. 1985. Comparability of introduced tiles and natural substrates for sampling lotic bacteria, algae, and macroinvertebrates. Fresh Biol 15: 21-30.

22. Kiffney PM, Clements WH. 1996. Effects of metals on stream macroinvertebrate assemblages from different altitudes. Eco Appl 6: 472-481.

23. Diamond JM, Winchester EL, Mackler DG, Gruber D. 1992. Use of the mayfly Stenonema Modestum (Heptageniidae) in subacute toxicity assessments. Environ Toxicol Chem 11: 415-425.

24. APHA. 1995. Standard methods for the examination of water and wastewater: Including bottom sediments and sludges. APHA. New York, USA.

25. Fowler J, Cohen L, Jarvis P. 1998. Practical statistics for field biology. $2^{\text {nd }}$ edition. John Wiley \& Sons Ltd. West Sussex, England.

26. U.S. Environmental Protection Agency. 2002. Short-term methods for estimating the chronic toxicity of effluents and receiving waters to freshwater organisms. EPA 821/R-02/013.

27. McKay RJ. 1992. Colonization by lotic macroinvetebrates: A review of processes and patterns. Can J Fish Aquat Sci 49: 617-626.

28. Virginia DEQ/DCR. 2002. Benthic TMDL reports for six impaired segments in the Potomac-Shenandoah and James River basins.

29. Quinn JM, Cooper AB, Stroud MJ, Burrell GP. 1997. Shade effects on stream periphyton and invertebrates: An experiment in streamside channels. New Zealand J Mar Freshwater Res 31: 665-683.

30. Lenat DR, Crawford JK. 1994. Effects of land use on water quality and aquatic biota of three North Carolina Piedmont streams. Hydrobiol 294: 185-199.

31. Hickey CW, Golding LA, Martin ML, Croker GF. 1999. Chronic toxicity of ammonia to New Zealand freshwater invertebrates: A mesocosm study. Arch Environ Contam Toxicol 37: 338-351.

32. Stewart NT. Treatment of rainbow trout (Oncorhynchus mykiss) raceway effluent using baffled sedimentation and Artificial substrates and characterization of nutrient leaching rates from settled rainbow trout (Oncorhynchus mykiss) sludge. Submitted in partial fulfillment of Master's thesis. Virginia Polytechnic Institute and State University. Blacksburg, VA. 
33. McCormick PV, Shuford RBE, Rawlik PS. 2004. Changes in macroinvertebrate community structure and function along a phosphorous gradient in the Florida Everglades. Hydrobiol 529: 113-132.

34. Hose GC, Hyne RV, Lim RP. 2003. Toxicity of endosulfan to Atalophlebia spp. (Ephemeroptera) in the laboratory, mesocosm, and field. Environ Toxicol Chem 22: 3062-3068. 


\section{Appendix A: Literature Review References}

Axler RP, Tikkanen C, Henneck J, Schuldt J, McDonald ME. 1997. Characteristics of effluent and sludge from two commercial rainbow trout farms in Minnesota. The Prog Fish-Cult 59: 161-172.

Bartsch MR, Cope WG, Rada RG. Effects of cadmium-spiked sediment on cadmium accumulation and bioturbation by nymphs of the burrowing mayfly Hexagenia bilineata. Water, Air, and Soil Pollut 109: 277-292.

Boaventura R, Pedro AM, Coimbra J, Lencastre E. 1997. Trout farm effluents: Characterization and impact on the receiving streams. Environ Pollut 95: 379-387.

Borgmann U, Ralph KM, Norwood WP. 1989. Toxicity test procedures for Hyallela azteca, and chronic toxicity of cadmium and pentachlorophenol to $\mathrm{H}$. azteca, Gammarus fasciatus, and Daphnia magna. Arch Environ Contam Toxicol 18: 756764.

Borgmann U. 1994. Chronic toxicity of ammonia to the amphipod Hyallela azteca; importance of ammonium ion and water hardness. Environ Pollut 86: 329-335.

Brown CA. 1996. Macroinvertebrate community patterns in relation to physicochemical parameters measured at two land-based trout farms affecting streams in the South-Western Cape, South Africa. Arch fuer Hydrobiologie 138: 57-76.

Camargo JA. 1992. Structural and trophic alterations in macrobenthic communities downstream from a fish farm outlet. Hydrobiol 242: 41-49.

Camargo JA. 1994. The importance of biological monitoring for the ecological risk-assessment of freshwater pollution: A case study. Environ Internat 20: 229-238. 
Clements WH, Van Hassel JH, Cherry DS, Cairns J. 1989. Colonization, variability, and the use of substratum-filled trays for biomonitoring benthic communities. Hydrobiol 173: 45-53.

Courtney LA, Clements WH. 1998. Effects of acidic pH on benthic macroinvertebrate communities in stream microcosms. Hydrobiol 379: 135-145.

Diamond JM, Winchester EL, Mackler DG, Gruber D. 1992. Use of the mayfly Stenonema Modestum (Heptageniidae) in subacute toxicity assessments. Environ Toxicol Chem 11: 415-425.

Doughty CR, McPhail CD. 1995. Monitoring the environmental impacts and consent compliance of freshwater fish farms. Aquacul Res 26: 557-565.

Duxbury C. 2003. The use of previously colonized multiplate artificial substrates in experimental microcosms. J Fresh Eco 18: 459-464.

Fries LT, Bowles DE. 2002. Water quality and macroinvertebrate community structure associated with a sportfish hatchery outfall. N Amer J of Aquacul 64: 257266.

Garcia-Ruiz R, Hall GH. 1996. Phosphorus fractionation and mobility in the food and faeces of hatchery reared rainbow trout (Onchorhynchus mykiss). Aquacul 145: 183-193.

Hatakeyama S, Shiraishi H, Uno S. 1997. Overall pesticide effects on growth and emergence of two species of Ephemeroptera in a model stream carrying pesticidepolluted river water. Ecotoxicol 6: 167-180. 
Hinshaw JM, Fornshell G. 2002. Effluents from raceways. 77-104 in Tomasso JR, editor. Aquaculture and the environment in the United States. U. S. Aquaculture Society, Baton Rouge, Louisiana.

Hose GC, Hyne RV, Lim RP. 2003. Toxicity of endosulfan to Atalophlebia spp. (Ephemeroptera) in the laboratory, mesocosm, and field. Environ Toxicol Chem 22: 3062-3068.

Kendra W. 1991. Quality of salmonid hatchery effluents during a summer low-flow season. Trans Amer Fisheries Soc 120: 43-51.

Kennedy AJ, Cherry DS, Currie RJ. 2004. Evaluation of ecologically relevant bioassays for a lotic system impacted by a coal-mine effluent, using Isonychia. Environ Monit Assess 95: 37-55.

Kiffney PM, Clements WH. 1996. Effects of metals on stream macroinvertebrate assemblages from different altitudes. Eco Appl 6: 472-481.

Landrum PF, Steevens JA, McElroy M, Gossiaux DC, Lewis JS, Robinson SD. Time-dependent toxicity of dichlorodiphenyldichloroethylene to Hyallela azteca. Environ Toxicol Chem 24: 211-218.

Loch DD, West JL, Perlmutter DG. 1996. The effect of trout farm effluent on the taxa richness of benthic macroinvertebrates. Aquacul 147: 37-55.

Maillard VM. 1998. Characterization, treatment, and improvement of aquaculture effluents. Master's thesis. Virginia Polytechnic Institute and State University, Blacksburg, Virginia.

Merrit RW, Cummins KW, editors. 1996. An introduction to the aquatic insects of North America. $3^{\text {rd }}$ edition. Kendall/Hunt Publishing Company, Dubuque, Iowa. 
Myrick CA. Ecological impacts of escaped organisms. 225-245 in Tomasso JR, editor. Aquaculture and the environment in the United States. U. S. Aquaculture Society, Baton Rouge, Louisiana.

Naylor SJ, Moccia RD, Durant GM. 1999. The chemical composition of settleable solid fish waste (manure) from commercial rainbow trout farms in Ontario, Canada. N Amer J Aquacul 61: 21-26.

Nuutinen S, Landrum PF, Shuler LJ, Kukkonen JVK, Lydy MJ. 2003.

Toxicokinetics of organic contaminants in Hyallela azteca. Arch Environ Contam Toxicol 44: 467-475.

Pontasch KW, Cairns J. 1989. Establishing and maintaining laboratory-based microcosms of riffle insect communities: Their potential for multispecies toxicity tests. Hydrobiol 175: 49-60.

Pontasch KW, Cairns J. 1991. Multispecies toxicity tests using indigenous organisms: Predicting the effects of complex effluents in streams. Arch Environ Contam Toxicol 20: 103-112.

Rennert B. 1994. Water pollution by a land-based trout farm. J Appl Ichthyol 10: 373-378.

Rosenberg DM, Resh VH. 1993. Introduction to freshwater biomonitoring and benthic macroinvertebrates. 1-9 in Rosenberg DM, Resh VH, editors. Freshwater biomonitoring and benthic macroinvertebrates. Chapman and Hill, New York, NY.

Selong JH, Helfrich LA. 1998. Impacts of trout culture effluent on water quality and biotic communities in Virginia headwater streams. The Prog Fish-Culturist 60: 247-262. 
Shriner C, Gregory T. 1984. Use of artificial streams for toxicological research. CRC Crit Rev Toxicol 13: 253-280.

Stephens WW, Farris JL. 2004. Instream community assessment of aquaculture effluents. Aquacul 231: 149-162.

U.S. Environmental Protection Agency. 2000. Methods for measuring the toxicity and bioaccumulation of sediment-associated contaminants with freshwater invertebrates. EPA 600/R-99/064. 


\section{Appendix B: Figures and Tables Legend}

Figure 3.1 Mean total and EPT abundance in 10 day multispecies test. Initial values are numbers recorded from samples collected on day of transfer to the trout farm. Colonizing values are numbers recorded from samples placed back in the colonizing stream on day of transfer.

Figure 3.2 Mean total and EPT abundance in 15 day multispecies test.

Figure 3.3 Mean total and EPT abundance in 21 day multispecies test.

Table 3.1 Shapiro-Wilk's Test for normality for Test 1 data at a) 20 days and b) 28 days. The critical value at a significance level of 0.05 and 12 observations is 0.859 . RP is the response proportion, or number of survivors divided by initial number of amphipods. The columns labeled $X^{(i)}$ are the centered observations. Formulas for the procedure can be found in USEPA (2002).

Table 3.2 Shapiro-Wilk's Test of normality for Test 2 data at a) 20 days and b) 28 days.

Table 3.3 Bartlett's Test of homogeneity of variance for Test 1 data at a) 20 days and b) 28 days. $S_{i}{ }^{2}$ is the standard error; formulas for the other parameters can be found in USEPA (2002). When the variances are the same, $B$ is approximately distributed as chi square with $p$ - 1 degrees of freedom. For a 0.05 level of significance with 2 degrees of freedom, the critical value is 5.99.

Table 3.4 Bartlett's Test of homogeneity of variance for Test 2 data at a) 20 days and b) 28 days. 
Table 3.5 Dunnett's Procedure for Test 1 data at a) 20 days and b) 28 days. The critical value for 9 degrees of freedom and 2 concentrations excluding the control is 2.18. If the calculated $t$ statistic is less than this value, the difference in survival is significant. The t statistics for the spring water, above sedimentation basin, and below sedimentation basin treatments are represented by $t_{s}, t_{a b o v e}$, and $t_{\text {below, }}$ respectively. Formulas for the procedure can be found in USEPA (2002).

Table 3.6 Dunnett's Procedure for Test 2 data at a) 20 days and b) 28 days.

Table 3.7 One-way ANOVA of a) total invertebrate abundance and b) total EPT abundance for the 10 day multispecies test. The critical $F$ value with 2 and 2 degrees of freedom is 19.000. The calculated value is determined by dividing the between samples variance by the within samples variance, represented by $s^{2}$. Formulas for the procedure can be found in Fowler et al. (1998).

Table 3.8 One-way ANOVA of a) total invertebrate abundance and b) total EPT abundance for the 15 day multispecies test.

Table 3.9 One-way ANOVA of a) total invertebrate abundance and b) total EPT abundance for the 21 day multispecies test.

Table 3.10 Tukey test of total invertebrate abundance to determine which samples are significantly different. Differences in means greater than the calculated statistic, $T$, are considered significant. The formula for the $T$ statistic can be found in Fowler et al. (1998).

Table 3.11 Two-tailed F-test and t-test for the Heptageniidae field test data to determine homogeneity of variance and significance of differences, respectively. The tabulated value for 6 degrees of freedom in the t-test is 2.447; a calculated value above this is considered significant. The formulas for the F-test and t-test can be found in Fowler et al. (1998). 
Table 3.12 List of taxa from 10 day multispecies test.

Table 3.13 List of taxa from 15 day multispecies test.

Table 3.14 List of taxa from 21 day multispecies test. 


\section{Appendix C: Figures and Tables}

Figure 3.1

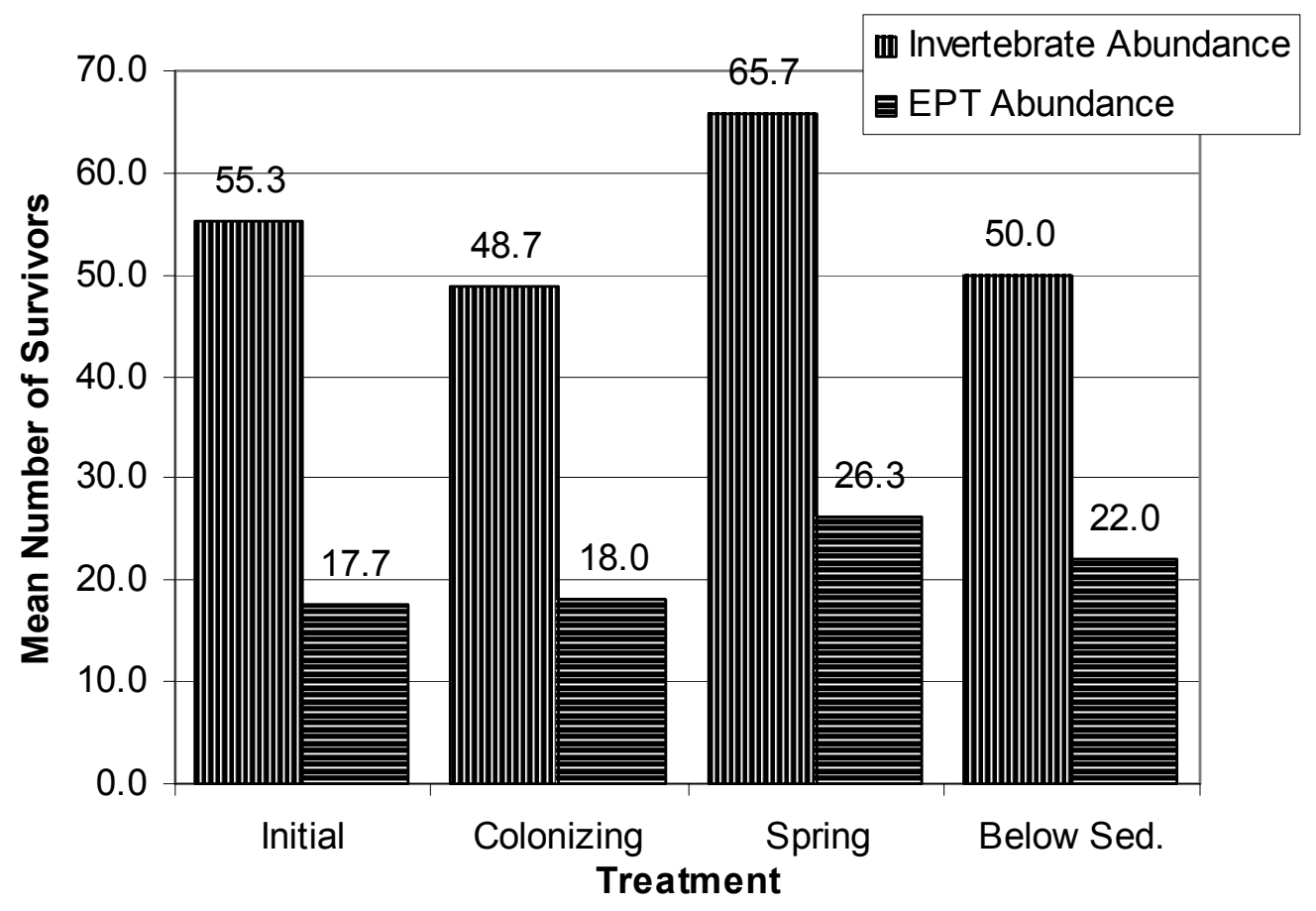


Figure 3.2

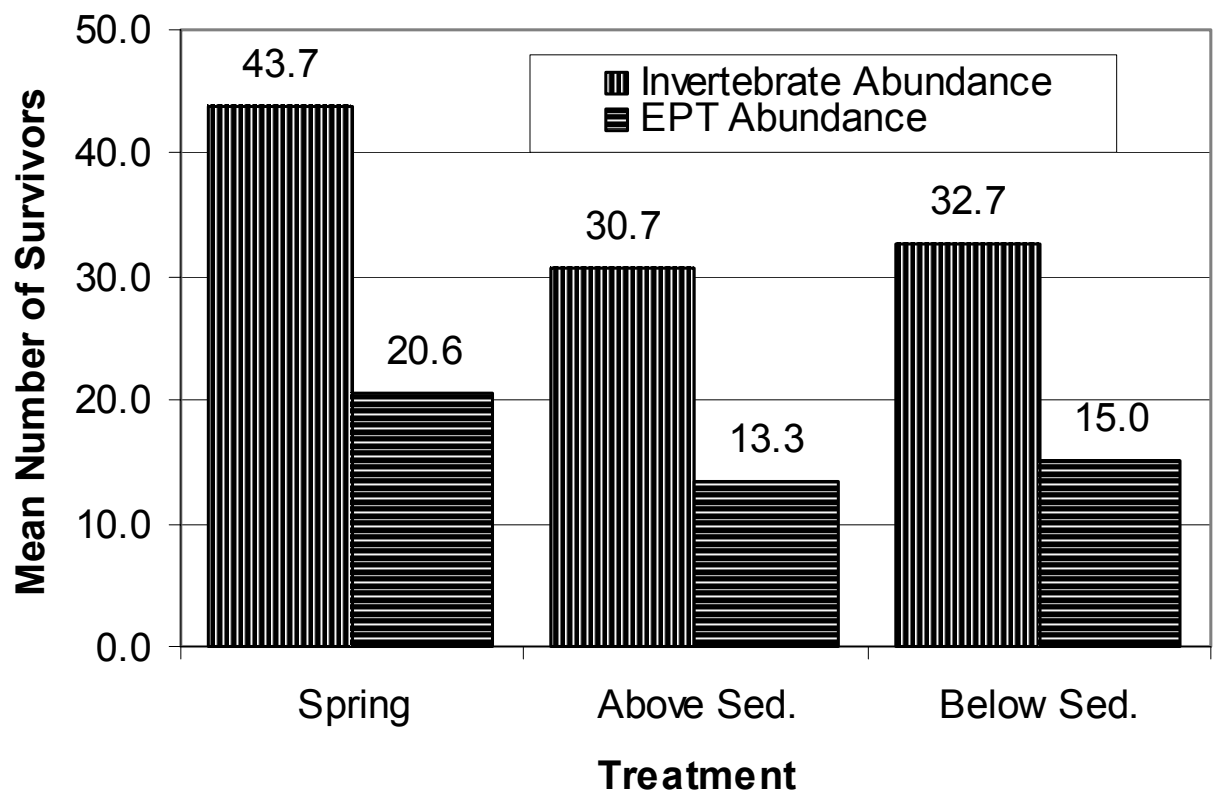


Figure 3.3

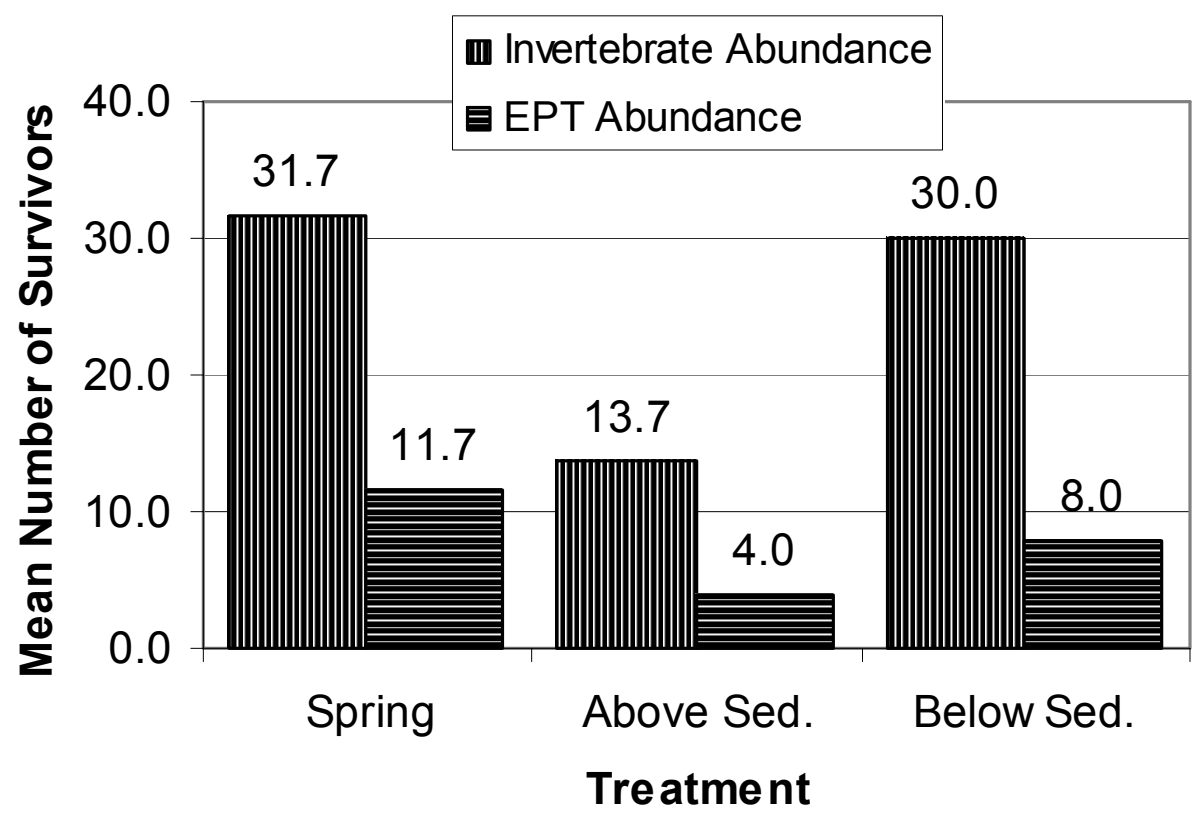


Table 3.1

a)

\begin{tabular}{|l|l|l|l|l|}
\hline Treatment & RP & Arc Sin RP & Mean & \multicolumn{1}{c|}{$\mathbf{X}^{(\mathbf{i})}$} \\
\hline Spring 1 & 0.583 & 0.869 & 0.958 & -0.089 \\
\hline Spring 2 & 0.583 & 0.869 & 0.958 & -0.089 \\
\hline Spring 3 & 0.750 & 1.047 & 0.958 & 0.089 \\
\hline Spring 4 & 0.750 & 1.047 & 0.958 & 0.089 \\
\hline Above Sed 1 & 0.750 & 1.047 & 0.871 & 0.176 \\
\hline Above Sed 2 & 0.667 & 0.956 & 0.871 & 0.085 \\
\hline Above Sed 3 & 0.583 & 0.869 & 0.871 & -0.002 \\
\hline Above Sed 4 & 0.333 & 0.615 & 0.871 & -0.256 \\
\hline Below Sed 1 & 0.833 & 1.150 & 0.984 & 0.166 \\
\hline Below Sed 2 & 0.750 & 1.047 & 0.984 & 0.063 \\
\hline Below Sed 3 & 0.583 & 0.869 & 0.984 & -0.115 \\
\hline Below Sed 4 & 0.583 & 0.869 & 0.984 & -0.115 \\
\hline W=0.922 Because W is greater than the critical value, 0.859, the data are normally distributed. \\
\hline
\end{tabular}

b)

\begin{tabular}{|l|l|l|l|l|}
\hline Treatment & RP & Arc Sin RP & Mean & \multicolumn{1}{c|}{$\mathbf{X}^{(\mathbf{i})}$} \\
\hline Spring 1 & 0.250 & 0.524 & 0.345 & 0.179 \\
\hline Spring 2 & 0.167 & 0.421 & 0.345 & 0.076 \\
\hline Spring 3 & 0 & 0.145 & 0.345 & -0.200 \\
\hline Spring 4 & 0.083 & 0.292 & 0.345 & -0.053 \\
\hline Above Sed 1 & 0.583 & 0.869 & 0.764 & 0.105 \\
\hline Above Sed 2 & 0.500 & 0.785 & 0.764 & 0.021 \\
\hline Above Sed 3 & 0.500 & 0.785 & 0.764 & 0.021 \\
\hline Above Sed 4 & 0.333 & 0.615 & 0.764 & -0.149 \\
\hline Below Sed 1 & 0.417 & 0.702 & 0.591 & 0.111 \\
\hline Below Sed 2 & 0.250 & 0.524 & 0.591 & -0.067 \\
\hline Below Sed 3 & 0.250 & 0.524 & 0.591 & -0.067 \\
\hline Below Sed 4 & 0.333 & 0.615 & 0.591 & 0.024 \\
\hline W =0.954 Because W is greater than the critical value, 0.859, the data are normally distributed. \\
\hline
\end{tabular}


Table 3.2

a)

\begin{tabular}{|l|l|l|l|l|}
\hline Treatment & RP & Arc Sin RP & Mean & \multicolumn{1}{c|}{$\mathbf{X}^{(\mathbf{i})}$} \\
\hline Spring 1 & 0.333 & 0.615 & 0.872 & -0.257 \\
\hline Spring 2 & 0.667 & 0.956 & 0.872 & 0.084 \\
\hline Spring 3 & 0.750 & 1.047 & 0.872 & 0.175 \\
\hline Spring 4 & 0.583 & 0.869 & 0.872 & -0.003 \\
\hline Above Sed 1 & 0.667 & 0.956 & 0.759 & 0.197 \\
\hline Above Sed 2 & 0.417 & 0.702 & 0.759 & -0.057 \\
\hline Above Sed 3 & 0.167 & 0.421 & 0.759 & -0.338 \\
\hline Above Sed 4 & 0.667 & 0.956 & 0.759 & 0.197 \\
\hline Below Sed 1 & 0.417 & 0.702 & 0.828 & -0.126 \\
\hline Below Sed 2 & 0.500 & 0.785 & 0.828 & -0.043 \\
\hline Below Sed 3 & 0.583 & 0.869 & 0.828 & 0.041 \\
\hline Below Sed 4 & 0.667 & 0.956 & 0.828 & 0.128 \\
\hline W=0.926 Because W is greater than the critical value, 0.859, the data are normally distributed. \\
\hline
\end{tabular}

b)

\begin{tabular}{|l|l|l|l|l|}
\hline Treatment & RP & Arc Sin RP & Mean & \multicolumn{1}{c|}{$\mathbf{X}^{(\mathbf{i})}$} \\
\hline Spring 1 & 0.333 & 0.615 & 0.700 & -0.085 \\
\hline Spring 2 & 0.333 & 0.615 & 0.700 & -0.085 \\
\hline Spring 3 & 0.417 & 0.702 & 0.700 & 0.002 \\
\hline Spring 4 & 0.583 & 0.869 & 0.700 & 0.169 \\
\hline Above Sed 1 & 0.750 & 0.955 & 0.592 & 0.363 \\
\hline Above Sed 2 & 0.417 & 0.702 & 0.592 & 0.110 \\
\hline Above Sed 3 & 0.083 & 0.293 & 0.592 & -0.299 \\
\hline Above Sed 4 & 0.167 & 0.420 & 0.592 & -0.172 \\
\hline Below Sed 1 & 0.417 & 0.702 & 0.764 & -0.062 \\
\hline Below Sed 2 & 0.417 & 0.702 & 0.764 & -0.062 \\
\hline Below Sed 3 & 0.500 & 0.785 & 0.764 & -0.021 \\
\hline Below Sed 4 & 0.583 & 0.869 & 0.764 & 0.105 \\
\hline W $=0.926$ Because W is greater than the critical value, 0.859, the data are normally distributed. \\
\hline
\end{tabular}


Table 3.3

a)

\begin{tabular}{|c|c|c|c|}
\hline & \multicolumn{3}{|c|}{ Arc Sin Transformed Response Proportions } \\
\hline Replicate & Spring RP & Above Sed. RP & Below Sed. RP \\
\hline 1 & 0.869 & 1.047 & 1.150 \\
\hline 2 & 0.869 & 0.956 & 1.047 \\
\hline 3 & 1.047 & 0.869 & 0.869 \\
\hline 4 & 1.047 & 0.615 & 0.869 \\
\hline Mean & 0.958 & 0.871 & 0.984 \\
\hline $\mathbf{S}_{\mathrm{i}}^{2}$ & 0.010 & 0.013 & 0.019 \\
\hline I & 1 & 2 & 3 \\
\hline \multicolumn{4}{|c|}{$\begin{array}{l}V_{i}=3, p=3 \\
S^{2}=0.014 \\
C=1+[0.167 * 0.889]=1.148\end{array}$} \\
\hline \multicolumn{4}{|c|}{$\begin{array}{l}\mathrm{B}=0.275 \text { Because } \mathrm{B} \text { is less than the critical value, } 5.99 \text {, it is concluded that the variances are not } \\
\text { different. }\end{array}$} \\
\hline
\end{tabular}

b)

\begin{tabular}{|c|c|c|c|}
\hline & \multicolumn{3}{|c|}{ Arc Sin Transformed Response Proportions } \\
\hline Replicate & Spring RP & T1 RP & T2 RP \\
\hline 1 & 0.524 & 0.869 & 0.702 \\
\hline 2 & 0.421 & 0.785 & 0.524 \\
\hline 3 & 0.145 & 0.785 & 0.524 \\
\hline 4 & 0.292 & 0.615 & 0.615 \\
\hline Mean & 0.345 & 0.764 & 0.591 \\
\hline $\mathbf{S}_{\mathrm{i}}{ }^{2}$ & 0.027 & 0.011 & 0.007 \\
\hline I & 1 & 2 & 3 \\
\hline \multicolumn{4}{|c|}{$\begin{array}{l}V_{i}=3, p=3 \\
S^{2}=0.015 \\
C=1+[0.167 * 0.889]=1.148\end{array}$} \\
\hline $\begin{array}{l}\mathrm{B}=1.266 \text { Becaus } \\
\text { different. }\end{array}$ & & & not \\
\hline
\end{tabular}


Table 3.4

a)

\begin{tabular}{|c|c|c|c|}
\hline & \multicolumn{3}{|c|}{ Arc Sin Transformed Response Proportions } \\
\hline Replicate & Spring RP & T1 RP & T2 RP \\
\hline 1 & 0.615 & 0.956 & 0.702 \\
\hline 2 & 0.956 & 0.702 & 0.785 \\
\hline 3 & 1.047 & 0.421 & 0.869 \\
\hline 4 & 0.869 & 0.956 & 0.956 \\
\hline Mean & 0.872 & 0.759 & 0.828 \\
\hline $\mathbf{S}_{\mathbf{i}}{ }^{2}$ & 0.034 & 0.065 & 0.036 \\
\hline I & 1 & 2 & 3 \\
\hline \multicolumn{4}{|c|}{$\begin{array}{l}\mathrm{V}_{\mathrm{i}}=3, \mathrm{p}=3 \\
\mathrm{~S}^{2}=0.045 \\
\mathrm{C}=1+[0.167 * 0.889]=1.148\end{array}$} \\
\hline \multicolumn{4}{|c|}{$\begin{array}{l}\mathrm{B}=0.355 \text { Because } \mathrm{B} \text { is less than the critical value, } 5.99 \text {, it is concluded that the variances are not } \\
\text { different. }\end{array}$} \\
\hline
\end{tabular}

b)

\begin{tabular}{|c|c|c|c|}
\hline & \multicolumn{3}{|c|}{ Arc Sin Transformed Response Proportions } \\
\hline Replicate & Spring RP & T1 RP & T2 RP \\
\hline 1 & 0.615 & 0.955 & 0.702 \\
\hline 2 & 0.615 & 0.702 & 0.702 \\
\hline 3 & 0.702 & 0.293 & 0.785 \\
\hline 4 & 0.869 & 0.420 & 0.869 \\
\hline Mean & 0.700 & 0.592 & 0.764 \\
\hline $\mathbf{S}_{\mathrm{i}}{ }^{2}$ & 0.014 & 0.088 & 0.006 \\
\hline $\mathbf{I}$ & 1 & 2 & 3 \\
\hline $\mathrm{V}_{\mathrm{i}}=3, \mathrm{p}=3$ & $\mathrm{~S}^{2}=0.036$ \\
$\mathrm{C}=1+[0.167 * 0.889]=1.148$ & \\
\hline $\mathrm{B}=4.814 \quad$ Because B is less than the critical value, 5.99, it is concluded that the variances are not \\
different.
\end{tabular}


Table 3.5

a)

\begin{tabular}{|c|c|c|c|}
\hline Source & df & Sum of Squares & Mean Square \\
\hline Between & $3-1=2$ & 0.028 & 0.014 \\
\hline Within & $12-3=9$ & 0.193 & 0.021 \\
\hline Total & 11 & 0.221 & \\
\hline
\end{tabular}

Because the highest average proportion surviving was in the below sedimentation basin treatment after 20 days, the other two treatments are compared to it to determine if the differences are significant. $\mathrm{t}_{\mathrm{S}}=0.254$

$t_{\text {above }}=1.102$ Because both calculated values are less than the critical value, 2.18 , the differences are not significant.

b)

\begin{tabular}{|c|c|c|c|}
\hline Source & df & Sum of Squares & Mean Square \\
\hline Between & 2 & 0.354 & 0.177 \\
\hline Within & 9 & 0.136 & 0.015 \\
\hline Total & 11 & 0.490 & \\
\hline
\end{tabular}

Because the highest average proportion surviving was in the above sedimentation basin treatment after 28 days, the other two treatments are compared to it to determine if the differences are significant. $\mathrm{t}_{\mathrm{S}}=4.857$

$\mathrm{t}_{\text {below }}=2.006$ The spring water treatment is significantly lower than the above sedimentation basin water treatment. 
Table 3.6

a)

\begin{tabular}{|c|c|c|c|}
\hline Source & df & Sum of Squares & Mean Square \\
\hline Between & 2 & 0.026 & 0.013 \\
\hline Within & 9 & 0.335 & 0.037 \\
\hline Total & 11 & 0.361 & \\
\hline
\end{tabular}

Because the highest average proportion surviving was in the spring water treatment after 20 days, the other two treatments are compared to it to determine if the differences are significant.

$\mathrm{t}_{\mathrm{above}}=0.832$

$t_{\text {below }}=0.324$ Because both calculated values are less than the critical value, 2.18 , the differences are not significant.

b)

\begin{tabular}{|c|c|c|c|}
\hline Source & df & Sum of Squares & Mean Square \\
\hline Between & 2 & 0.060 & 0.030 \\
\hline Within & 9 & 0.325 & 0.036 \\
\hline Total & 11 & 0.385 & \\
\hline
\end{tabular}

Because the highest average proportion surviving was in the below sedimentation basin treatment after 28 days, the other two treatments are compared to it to determine if the differences are significant. $\mathrm{t}_{\mathrm{S}}=0.476$

$\mathrm{t}_{\mathrm{above}}=1.280$ Because both calculated values are less than the critical value, 2.18 , the differences are not significant. 


\section{Table 3.7}

a)

\begin{tabular}{|c|c|c|c|c|}
\hline & \multicolumn{3}{|c|}{ Square root transformed Total Invertebrates } & \multirow[b]{2}{*}{ Total } \\
\hline Replicate & Colonizing & Spring & $\begin{array}{c}\text { Below } \\
\text { Sedimentation }\end{array}$ & \\
\hline 1 & 6.708 & 9.165 & 7.141 & \\
\hline 2 & 7.348 & 7.280 & 7.280 & \\
\hline 3 & 6.856 & 7.746 & 6.782 & \\
\hline & & & & \\
\hline $\mathrm{n}$ & 3 & 3 & 3 & 9 \\
\hline$\Sigma \mathrm{x}$ & 20.912 & 24.191 & 21.203 & 66.306 \\
\hline Mean & 6.971 & 8.064 & 7.068 & \\
\hline $\mathrm{S}$ & 0.335 & 0.982 & 0.257 & \\
\hline $\mathrm{s}^{2}$ & 0.112 & 0.964 & 0.066 & \\
\hline$(\Sigma x)^{2}$ & 437.311 & 585.204 & 449.567 & \\
\hline$\sum \mathrm{x}^{2}$ & 145.995 & 196.996 & 149.988 & 492.979 \\
\hline \multicolumn{5}{|c|}{$\begin{array}{l}\mathrm{F}_{\max }=0.964 / 0.112=8.61 \text { Because the calculated value is less than the critical value, } 87.5 \text {, } \\
\text { it is concluded that the variances are homogeneous. }\end{array}$} \\
\hline $\begin{array}{l}\text { Source of } \\
\text { Variation }\end{array}$ & \multicolumn{2}{|l|}{ SS } & $\mathrm{df}$ & $\mathrm{F}$ \\
\hline Between & \multicolumn{2}{|c|}{2.196} & 1.0 & 2.881 \\
\hline Within & \multicolumn{2}{|c|}{2.285} & \multirow[t]{2}{*}{0.38} & \\
\hline Total & \multicolumn{2}{|c|}{4.481} & & \\
\hline
\end{tabular}

b)

\begin{tabular}{|c|c|c|c|c|}
\hline & \multicolumn{3}{|c|}{ Square root transformed Total EPT } & \multirow{2}{*}{ Total } \\
\hline Replicate & Colonizing & Spring & $\begin{array}{c}\text { Below } \\
\text { Sedimentation }\end{array}$ & \\
\hline 1 & 4.472 & 6.633 & 4.796 & \\
\hline 2 & 4.123 & 4.243 & 5.292 & \\
\hline 3 & 4.123 & 4.123 & 3.873 & \\
\hline $\mathrm{n}$ & 3 & & & 9 \\
\hline$\Sigma \mathrm{x}$ & 12.718 & 14.999 & 13.961 & 41.678 \\
\hline Mean & 4.239 & 5.000 & 4.654 & \\
\hline $\mathrm{s}$ & 0.041 & 2.004 & 0.518 & \\
\hline $\mathrm{s}^{2}$ & 0.202 & 1.416 & 0.720 & \\
\hline$(\Sigma \mathrm{x})^{2}$ & 161.748 & 224.970 & 194.910 & \\
\hline$\Sigma \mathrm{x}^{2}$ & 53.997 & 78.999 & 66.007 & 199.003 \\
\hline
\end{tabular}

$\mathrm{F}_{\max }=1.416 / 0.202=7.010$ Because the calculated value is less than the critical value, 87.5, it is concluded that the variances are homogeneous.

\begin{tabular}{|l|c|c|c|c|}
\hline $\begin{array}{l}\text { Source of } \\
\text { Variation }\end{array}$ & SS & df & $\mathrm{s}^{2}$ & F \\
\hline Between & 0.870 & 2 & 0.435 & \\
\hline Within & 5.127 & 6 & 0.854 & \\
\hline Total & 5.997 & 8 & & \\
\hline
\end{tabular}

Because the within samples variance is greater than the between samples variance, it is accepted that there is no significant difference in the EPT abundance between treatments. 


\section{Table 3.8}

a)

\begin{tabular}{|c|c|c|c|c|}
\hline & \multicolumn{3}{|c|}{ Square root transformed Total Invertebrates } & \multirow{2}{*}{ Total } \\
\hline Replicate & Spring & $\begin{array}{c}\text { Above } \\
\text { Sedimentation }\end{array}$ & $\begin{array}{c}\text { Below } \\
\text { Sedimentation }\end{array}$ & \\
\hline 1 & 6.481 & 5.099 & 5.291 & \\
\hline 2 & 7.000 & 4.899 & 5.831 & \\
\hline 3 & 6.324 & 5.657 & 6.000 & \\
\hline & & & & 9 \\
\hline $\mathrm{n}$ & 3 & 3 & 17.122 & 52.582 \\
\hline Mean & 19.805 & 15.655 & 5.707 & \\
\hline $\mathrm{s}$ & 0.602 & 5.218 & 0.370 & \\
\hline $\mathrm{s}^{2}$ & 0.125 & 0.392 & 0.137 & \\
\hline$(\Sigma \mathrm{x})^{2}$ & 392.238 & 245.079 & 293.163 & \\
\hline$\Sigma \mathrm{x}^{2}$ & 130.996 & 82.001 & 97.995 & 310.992 \\
\hline
\end{tabular}

$\mathrm{F}_{\max }=0.154 / 0.125=1.232$ Because the calculated value is less than the critical value, 87.5, it is concluded that the variances are homogeneous.

\begin{tabular}{|l|c|c|c|c|}
\hline $\begin{array}{l}\text { Source of } \\
\text { Variation }\end{array}$ & SS & df & $\mathrm{s}^{2}$ & $\mathrm{~F}$ \\
\hline Between & 2.953 & 2 & 1.476 & 10.619 \\
\hline Within & 0.832 & 6 & 0.139 & \\
\hline Total & 3.785 & 8 & & \\
\hline
\end{tabular}

The calculated value of $\mathrm{F}$ does not exceed the critical value, 19.000. Thus, the differences in total invertebrate abundance are not significant.

b)

\begin{tabular}{|c|c|c|c|c|}
\hline & \multicolumn{3}{|c|}{ Square root transformed Total EPT } & \multirow{2}{*}{ Total } \\
\hline Replicate & Spring & $\begin{array}{c}\text { Above } \\
\text { Sedimentation }\end{array}$ & $\begin{array}{c}\text { Below } \\
\text { Sedimentation }\end{array}$ & \\
\hline 1 & 4.690 & 3.317 & 3.317 & \\
\hline 2 & 5.000 & 3.464 & 4.359 & \\
\hline 3 & 3.873 & 4.123 & 3.873 & \\
\hline & & & & 9 \\
\hline $\mathrm{n}$ & 3 & 3 & 3 & 36.016 \\
\hline $\mathrm{x}$ & 13.563 & 10.904 & 11.549 & \\
\hline $\mathrm{s}$ & 4.521 & 3.635 & 3.850 & \\
\hline $\mathrm{s}^{2}$ & 0.583 & 0.429 & 0.522 & \\
\hline$(\Sigma \mathrm{x})^{2}$ & 0.340 & 0.184 & 0.272 & \\
\hline$\Sigma \mathrm{x}^{2}$ & 183.955 & 118.897 & 133.379 & \\
\hline $\mathrm{F}$ & 61.996 & 40.001 & 45.003 & 147.000 \\
\hline
\end{tabular}

$\mathrm{F}_{\max }=0.340 / 0.184=1.848$ Because the calculated value is less than the critical value, 87.5 , it is concluded that the variances are homogeneous.

\begin{tabular}{|c|c|c|c|c|}
\hline $\begin{array}{l}\text { Source of } \\
\text { Variation }\end{array}$ & SS & $\mathrm{df}$ & $\mathrm{s}^{2}$ & $\mathrm{~F}$ \\
\hline Between & 1.282 & 2 & 0.641 & 2.419 \\
\hline Within & 1.590 & 6 & 0.265 & \\
\hline Total & 2.872 & 8 & & \\
\hline
\end{tabular}


Table 3.9

a)

\begin{tabular}{|c|c|c|c|c|}
\hline & \multicolumn{3}{|c|}{ Square root transformed Total Invertebrates } & \multirow[b]{2}{*}{ Total } \\
\hline Replicate & Spring & $\begin{array}{c}\text { Above } \\
\text { Sedimentation }\end{array}$ & $\begin{array}{c}\text { Below } \\
\text { Sedimentation }\end{array}$ & \\
\hline 1 & 5.831 & 3.742 & 5.291 & \\
\hline 2 & 6.000 & 3.873 & 5.291 & \\
\hline 3 & 5.000 & 3.464 & 5.831 & \\
\hline & & & & 0 \\
\hline$\sum \mathrm{x}$ & 16.831 & 11.079 & 16.413 & 44.323 \\
\hline Mean & 5.610 & 3.693 & 5.471 & \\
\hline $\mathrm{S}$ & 0.535 & 0.295 & 0.311 & \\
\hline $\mathrm{s}^{2}$ & 0.286 & 0.087 & 0.097 & \\
\hline$(\Sigma \mathrm{x})^{2}$ & 283.282 & 122.744 & 269.386 & \\
\hline$\sum \mathrm{x}^{2}$ & 95.000 & 41.002 & 89.990 & 225.992 \\
\hline \multicolumn{5}{|c|}{$\begin{array}{l}\mathrm{F}_{\max }=1.169 / 0.286=4.087 \text { Because the calculated value is less than the critical value, } 87.5 \text {, } \\
\text { it is concluded that the variances are homogeneous. }\end{array}$} \\
\hline $\begin{array}{l}\text { Source of } \\
\text { Variation }\end{array}$ & SS & df & $\mathrm{s}^{2}$ & $\mathrm{~F}$ \\
\hline Between & 6.856 & 2 & 3.42 & 24.141 \\
\hline Within & 0.855 & 6 & 0.14 & \\
\hline Total & 7.711 & 8 & & \\
\hline
\end{tabular}

b)

\begin{tabular}{|c|c|c|c|c|}
\hline & \multicolumn{3}{|c|}{ Square root transformed Total EPT } & \multirow{2}{*}{ Total } \\
\hline Replicate & Spring & $\begin{array}{c}\text { Above } \\
\text { Sedimentation }\end{array}$ & $\begin{array}{c}\text { Below } \\
\text { Sedimentation }\end{array}$ & \\
\hline 1 & 2.828 & 1.732 & 2.449 & \\
\hline 2 & 3.742 & 2.646 & 2.236 & \\
\hline 3 & 3.606 & 1.414 & 3.606 & \\
\hline $\mathrm{n}$ & 3 & & & 9 \\
\hline$\Sigma \mathrm{x}$ & 10.176 & 5.792 & 8.291 & 24.259 \\
\hline Mean & 3.392 & 1.931 & 2.764 & \\
\hline $\mathrm{s}$ & 0.493 & 0.640 & 0.737 & \\
\hline $\mathrm{s}^{2}$ & 0.243 & 0.409 & 0.543 & \\
\hline$(\Sigma \mathrm{x})^{2}$ & 103.551 & 33.547 & 68.741 & \\
\hline$\Sigma \mathrm{x}^{2}$ & 35.003 & 12.000 & 24.000 & 71.003 \\
\hline
\end{tabular}

$\mathrm{F}_{\max }=0.543 / 0.243=2.234$ Because the calculated value is less than the critical value, 87.5 , it is concluded that the variances are homogeneous.

\begin{tabular}{|c|c|c|c|c|}
\hline $\begin{array}{l}\text { Source of } \\
\text { Variation } \\
\end{array}$ & SS & $\mathrm{df}$ & $\mathrm{s}^{2}$ & $\mathrm{~F}$ \\
\hline Between & 3.224 & 2 & 1.612 & 4.050 \\
\hline Within & 2.390 & 6 & 0.398 & \\
\hline Total & 5.614 & 8 & & \\
\hline
\end{tabular}


Table 3.10

\begin{tabular}{|l|l|l|}
\hline \multicolumn{1}{|c|}{ Sample } & \multicolumn{1}{|c|}{ Above Sedimentation Basin } & \multicolumn{1}{c|}{ Below Sedimentation Basin } \\
\hline $\begin{array}{l}\text { Spring } \\
\text { mean }=5.610\end{array}$ & $\begin{array}{l}\text { (spring }- \text { above sed.) } \\
5.610-3.693=1.917\end{array}$ & (spring - below sed.) \\
\hline $\begin{array}{l}\text { Above Sed. Basin } \\
\text { mean = 3.693 }\end{array}$ & & (above sed. - below sed.) \\
\hline $\begin{array}{l}\text { Below Sed. Basin } \\
\text { mean }=5.471\end{array}$ & & $3.693-5.471=1.778$ \\
\hline
\end{tabular}

$\mathrm{T}=0.944 \quad$ The difference between the spring and the above sedimentation basin treatments and the difference between the below sedimentation basin and above sedimentation basin treatments are significant. 
Table 3.11

\begin{tabular}{|c|c|c|c|}
\hline \multirow[b]{2}{*}{ Replicate } & \multicolumn{2}{|c|}{$\begin{array}{l}\text { Arc Sine Square root transformed } \\
\text { response proportions }\end{array}$} & \multirow[b]{2}{*}{ Total } \\
\hline & Spring & $\begin{array}{c}\text { Below } \\
\text { Sedimentation }\end{array}$ & \\
\hline 1 & 1.249 & 0.685 & \\
\hline 2 & 0.991 & 0.785 & \\
\hline 3 & 0.991 & 0.785 & \\
\hline 4 & 0.991 & 0.685 & \\
\hline & & & \\
\hline $\mathrm{n}$ & 4 & 4 & 8 \\
\hline$\sum x$ & 4.222 & 3.040 & \\
\hline Mean & 1.056 & 0.735 & \\
\hline $\mathrm{s}$ & 0.130 & 0.063 & \\
\hline $\mathrm{s}^{2}$ & 0.017 & 0.004 & \\
\hline \multicolumn{4}{|c|}{$\begin{array}{l}F_{\max }=0.017 / 0.004=4.25 \text { Because the calculated value is less than the } \\
\text { critical value, } 15.44 \text {, it is concluded that the variances are homogeneous. }\end{array}$} \\
\hline \multicolumn{4}{|c|}{$\begin{array}{l}\mathrm{t}=(1.056-0.735) / 0.072=4.43 \text { Because the calculated } \mathrm{t} \text { is greater than } \\
\text { the tabulated value, } 2.447 \text {, the difference is considered significant. }\end{array}$} \\
\hline
\end{tabular}


Table 3.12

\begin{tabular}{|c|c|c|}
\hline Sample & Family & Count \\
\hline Initial 1 & Ephemerellidae & 10 \\
\hline Initial 1 & Tipulidae & 5 \\
\hline Initial 1 & Perlodidae & 7 \\
\hline Initial 1 & Hydropsychidae & 3 \\
\hline Initial 1 & Trichoptera pupae & 2 \\
\hline Initial 1 & Chironomidae & 16 \\
\hline Initial 1 & Elmidae & 2 \\
\hline Initial 2 & Tipulidae & 3 \\
\hline Initial 2 & Decapoda & 1 \\
\hline Initial 2 & Oligochaeta & 1 \\
\hline Initial 2 & Perlodidae & 1 \\
\hline Initial 2 & Hydropsychidae & 1 \\
\hline Initial 2 & Elmidae & 5 \\
\hline Initial 2 & Chironomidae & 44 \\
\hline Initial 2 & Ephemerellidae & 2 \\
\hline Initial 2 & Heptageniidae & 1 \\
\hline Initial 2 & Perlidae & 1 \\
\hline Initial 2 & Leptophlebiidae & 10 \\
\hline Initial 3 & Perlodidae & 3 \\
\hline Initial 3 & Decapoda & 2 \\
\hline Initial 3 & Limnephilidae & 1 \\
\hline Initial 3 & Elmidae & 3 \\
\hline Initial 3 & Trichoptera pupa & 1 \\
\hline Initial 3 & Heptageniidae & 2 \\
\hline Initial 3 & Leptophlebiidae & 3 \\
\hline Initial 3 & Ephemerellidae & 4 \\
\hline Initial 3 & Chironomidae & 21 \\
\hline Spring 1 & Tipulidae & 4 \\
\hline Spring 1 & Perlodidae & 1 \\
\hline Spring 1 & Gomphidae & 1 \\
\hline Spring 1 & Isonychiidae & 7 \\
\hline Spring 1 & Heptageniidae & 1 \\
\hline Spring 1 & Hydropsychidae & 2 \\
\hline Spring 1 & Elmidae & 5 \\
\hline Spring 1 & Ephemerellidae & 13 \\
\hline Spring 1 & Trichoptera pupa & 1 \\
\hline Spring 1 & Chironomidae & 30 \\
\hline Spring 2 & Tipulidae & 5 \\
\hline Spring 2 & Trichoptera pupa & 1 \\
\hline Spring 2 & Plecoptera adult & 1 \\
\hline Spring 2 & Heptageniidae & 1 \\
\hline Spring 2 & Chironomidae & 29 \\
\hline Spring 2 & Ephemerellidae & 12 \\
\hline Spring 2 & Elmidae & 1 \\
\hline Spring 2 & Perlodidae & 3 \\
\hline Spring 3 & Decapoda & 2 \\
\hline Spring 3 & Tipulidae & 3 \\
\hline Spring 3 & Limnephilidae & 1 \\
\hline Spring 3 & Perlodidae & 1 \\
\hline Spring 3 & Corydalidae & 1 \\
\hline
\end{tabular}




\begin{tabular}{|c|c|c|}
\hline Spring 3 & Hydropsychidae & 1 \\
\hline Spring 3 & Trichoptera pupa & 1 \\
\hline Spring 3 & Elmidae & 3 \\
\hline Spring 3 & Chironomidae & 34 \\
\hline Spring 3 & Leptophlebiidae & 6 \\
\hline Spring 3 & Ephemeridae & 2 \\
\hline Spring 3 & Ephemerellidae & 5 \\
\hline Colonizing 1 & Tipulidae & 1 \\
\hline Colonizing 1 & Perlodidae & 1 \\
\hline Colonizing 1 & Hydropsychidae & 4 \\
\hline Colonizing 1 & Heptageniidae & 2 \\
\hline Colonizing 1 & Ephemeridae & 5 \\
\hline Colonizing 1 & Nemouridae & 1 \\
\hline Colonizing 1 & Leptophlebiidae & 1 \\
\hline Colonizing 1 & Elmidae & 3 \\
\hline Colonizing 1 & Hydracarina & 1 \\
\hline Colonizing 1 & Ephemerellidae & 6 \\
\hline Colonizing 1 & Chironomidae & 29 \\
\hline Colonizing 2 & Perlodidae & 4 \\
\hline Colonizing 2 & Tipulidae & 1 \\
\hline Colonizing 2 & Ephemeridae & 1 \\
\hline Colonizing 2 & Heptageniidae & 3 \\
\hline Colonizing 2 & Leptophlebiidae & 2 \\
\hline Colonizing 2 & Ephemerellidae & 7 \\
\hline Colonizing 2 & Elmidae & 1 \\
\hline Colonizing 2 & Chironomidae & 26 \\
\hline Colonizing 3 & Tipulidae & 2 \\
\hline Colonizing 3 & Oligochaeta & 1 \\
\hline Colonizing 3 & Corydalidae & 2 \\
\hline Colonizing 3 & Perlodidae & 3 \\
\hline Colonizing 3 & Heptageniidae & 6 \\
\hline Colonizing 3 & Ephemerellidae & 6 \\
\hline Colonizing 3 & Leptophlebiidae & 2 \\
\hline Colonizing 3 & Chironomidae & 25 \\
\hline Below Sedimentation 1 & Decapoda & 1 \\
\hline Below Sedimentation 1 & Tipulidae & 1 \\
\hline Below Sedimentation 1 & Perlodidae & 3 \\
\hline Below Sedimentation 1 & Isonychiidae & 1 \\
\hline Below Sedimentation 1 & Hydropsychidae & 1 \\
\hline Below Sedimentation 1 & Heptageniidae & 10 \\
\hline Below Sedimentation 1 & Ephemerellidae & 8 \\
\hline Below Sedimentation 1 & Chironomidae & 26 \\
\hline Below Sedimentation 2 & Tipulidae & 2 \\
\hline Below Sedimentation 2 & Oligochaeta & 1 \\
\hline Below Sedimentation 2 & Hydropsychidae & 4 \\
\hline Below Sedimentation 2 & Elmidae & 1 \\
\hline Below Sedimentation 2 & Perlodidae & 6 \\
\hline Below Sedimentation 2 & Heptageniidae & 9 \\
\hline Below Sedimentation 2 & Ephemerellidae & 8 \\
\hline Below Sedimentation 2 & Chironomidae & 22 \\
\hline Below Sedimentation 3 & Decapoda & 1 \\
\hline Below Sedimentation 3 & Trichoptera pupa & 1 \\
\hline Below Sedimentation 3 & Perlodidae & 3 \\
\hline
\end{tabular}




\begin{tabular}{|c|c|c|}
\hline Below Sedimentation 3 & Heptageniidae & 7 \\
\hline Below Sedimentation 3 & Ephemerellidae & 3 \\
\hline Below Sedimentation 3 & Elmidae & 1 \\
\hline Below Sedimentation 3 & Chironomidae & 28 \\
\hline Below Sedimentation 3 & Nemouridae & 1 \\
\hline
\end{tabular}


Table 3.13

\begin{tabular}{|c|c|c|}
\hline Sample & Family & Count \\
\hline Initial 1 & Oligochaeta & 1 \\
\hline Initial 1 & Tipulidae & 3 \\
\hline Initial 1 & Trichoptera pupa & 1 \\
\hline Initial 1 & Perlodidae & 2 \\
\hline Initial 1 & Elmidae & 2 \\
\hline Initial 1 & Nemouridae & 3 \\
\hline Initial 1 & Heptageniidae & 6 \\
\hline Initial 1 & Ephemerellidae & 5 \\
\hline Initial 1 & Chironomidae & 15 \\
\hline Initial 1 & Leptophlebiidae & 5 \\
\hline Initial 2 & Tipulidae & 2 \\
\hline Initial 2 & Decapoda & 1 \\
\hline Initial 2 & Corydalidae & 1 \\
\hline Initial 2 & Hydropsychidae & 1 \\
\hline Initial 2 & Nemouridae & 3 \\
\hline Initial 2 & Perlodidae & 2 \\
\hline Initial 2 & Heptageniidae & 3 \\
\hline Initial 2 & Ephemerellidae & 14 \\
\hline Initial 2 & Leptophlebiidae & 4 \\
\hline Initial 2 & Chironomidae & 10 \\
\hline Colonizing & Tipulidae & 1 \\
\hline Colonizing & Decapoda & 2 \\
\hline Colonizing & Heptageniidae & 3 \\
\hline Colonizing & Ephemerellidae & 1 \\
\hline Colonizing & Leptophlebiidae & 10 \\
\hline Colonizing & Ephemeroptera adult & 1 \\
\hline Colonizing & Chironomidae & 24 \\
\hline Colonizing & Elmidae & 2 \\
\hline Spring 1 & Tipulidae & 1 \\
\hline Spring 1 & Isonychiidae & 4 \\
\hline Spring 1 & Trichoptera pupae & 3 \\
\hline Spring 1 & Heptageniidae & 13 \\
\hline Spring 1 & Perlodidae & 2 \\
\hline Spring 1 & Chironomidae & 19 \\
\hline Spring 2 & Tipulidae & 2 \\
\hline Spring 2 & Ephemeroptera adult & 2 \\
\hline Spring 2 & Trichoptera pupae & 2 \\
\hline Spring 2 & Plecoptera adult & 1 \\
\hline Spring 2 & Heptageniidae & 4 \\
\hline Spring 2 & Elmidae & 1 \\
\hline Spring 2 & Perlodidae & 1 \\
\hline Spring 2 & Ephemerellidae & 10 \\
\hline Spring 2 & Isonychiidae & 4 \\
\hline Spring 2 & Leptophlebiidae & 1 \\
\hline Spring 2 & Chironomidae & 21 \\
\hline Spring 3 & Tipulidae & 3 \\
\hline Spring 3 & Limnephilidae & 1 \\
\hline Spring 3 & Heptageniidae & 2 \\
\hline Spring 3 & Hydropsychidae & 1 \\
\hline Spring 3 & Corydalidae & 1 \\
\hline
\end{tabular}




\begin{tabular}{|c|c|c|}
\hline Spring 3 & Elmidae & 1 \\
\hline Spring 3 & Trichoptera pupa & 1 \\
\hline Spring 3 & Isonychiidae & 1 \\
\hline Spring 3 & Nemouridae & 1 \\
\hline Spring 3 & Leptophlebiidae & 8 \\
\hline Spring 3 & Chironomidae & 20 \\
\hline Above Sedimentation 1 & Corydalidae & 1 \\
\hline Above Sedimentation 1 & Elmidae & 1 \\
\hline Above Sedimentation 1 & Leptophlebiidae & 5 \\
\hline Above Sedimentation 1 & Perlodidae & 1 \\
\hline Above Sedimentation 1 & Chironomidae & 13 \\
\hline Above Sedimentation 1 & Heptageniidae & 5 \\
\hline Above Sedimentation 2 & Trichoptera pupa & 1 \\
\hline Above Sedimentation 2 & Perlodidae & 2 \\
\hline Above Sedimentation 2 & Ephemerellidae & 1 \\
\hline Above Sedimentation 2 & Tipulidae & 1 \\
\hline Above Sedimentation 2 & Leptophlebiidae & 8 \\
\hline Above Sedimentation 2 & Heptageniidae & 1 \\
\hline Above Sedimentation 2 & Chironomidae & 10 \\
\hline Above Sedimentation 3 & Tipulidae & 2 \\
\hline Above Sedimentation 3 & Limnephilidae & 2 \\
\hline Above Sedimentation 3 & Heptageniidae & 2 \\
\hline Above Sedimentation 3 & Leptophlebiidae & 13 \\
\hline Above Sedimentation 3 & Chironomidae & 13 \\
\hline Below Sedimentation 1 & Calopterygidae & 1 \\
\hline Below Sedimentation 1 & Heptageniidae & 1 \\
\hline Below Sedimentation 1 & Corydalidae & 1 \\
\hline Below Sedimentation 1 & Diptera pupa & 1 \\
\hline Below Sedimentation 1 & Leptophlebiidae & 10 \\
\hline Below Sedimentation 1 & Chironomidae & 12 \\
\hline Below Sedimentation 2 & Heptageniidae & 5 \\
\hline Below Sedimentation 2 & Ephemeroptera adult & 1 \\
\hline Below Sedimentation 2 & Leptophlebiidae & 12 \\
\hline Below Sedimentation 2 & Chironomidae & 15 \\
\hline Below Sedimentation 2 & Perlodidae & 1 \\
\hline Below Sedimentation 3 & Tipulidae & 1 \\
\hline Below Sedimentation 3 & Corydalidae & 1 \\
\hline Below Sedimentation 3 & Limnephilidae & 1 \\
\hline Below Sedimentation 3 & Heptageniidae & 4 \\
\hline Below Sedimentation 3 & Trichoptera pupa & 1 \\
\hline Below Sedimentation 3 & Chironomidae & 19 \\
\hline Below Sedimentation 3 & Leptophlebiidae & 9 \\
\hline
\end{tabular}


Table 3.14

\begin{tabular}{|c|c|c|}
\hline Sample & Family & Count \\
\hline Colonizing & Decapoda & 2 \\
\hline Colonizing & Tipulidae & 5 \\
\hline Colonizing & Limnephilidae & 2 \\
\hline Colonizing & Diptera adult & 1 \\
\hline Colonizing & Chironomidae & 5 \\
\hline Colonizing & Oligochaeta & 1 \\
\hline Colonizing & Heptageniidae & 4 \\
\hline Colonizing & Leptophlebiidae & 9 \\
\hline Colonizing & Ephemerellidae & 1 \\
\hline Colonizing & Elmidae & 4 \\
\hline Colonizing & Trichoptera pupa & 1 \\
\hline Colonizing & Isonychia & 1 \\
\hline Spring 1 & Limnephilidae & 1 \\
\hline Spring 1 & Gastropoda & 1 \\
\hline Spring 1 & Perlodidae & 1 \\
\hline Spring 1 & Tipulidae & 2 \\
\hline Spring 1 & Chironomidae & 23 \\
\hline Spring 1 & Leptophlebiidae & 4 \\
\hline Spring 1 & Heptageniidae & 1 \\
\hline Spring 1 & Isonychiidae & 1 \\
\hline Spring 1 & Diptera pupa & 1 \\
\hline Spring 2 & Tipulidae & 4 \\
\hline Spring 2 & Chironomidae & 16 \\
\hline Spring 2 & Diptera pupae & 2 \\
\hline Spring 2 & Hydropsychidae & 1 \\
\hline Spring 2 & Perlodidae & 2 \\
\hline Spring 2 & Heptageniidae & 5 \\
\hline Spring 2 & Limnephilidae & 1 \\
\hline Spring 2 & Leptophlebiidae & 5 \\
\hline Spring 3 & Tipulidae & 3 \\
\hline Spring 3 & Chironomidae & 8 \\
\hline Spring 3 & Isonychiidae & 1 \\
\hline Spring 3 & Decapoda & 1 \\
\hline Spring 3 & Heptageniidae & 11 \\
\hline Spring 3 & Perlodidae & 1 \\
\hline Above Sedimentation 1 & Leptophlebiidae & 2 \\
\hline Above Sedimentation 1 & Corydalidae & 1 \\
\hline Above Sedimentation 1 & Chironomidae & 5 \\
\hline Above Sedimentation 1 & Diptera pupae & 2 \\
\hline Above Sedimentation 2 & Plecoptera adult & 1 \\
\hline Above Sedimentation 2 & Decapoda & 2 \\
\hline Above Sedimentation 2 & Tipulidae & 1 \\
\hline Above Sedimentation 2 & Leptophlebiidae & 5 \\
\hline Above Sedimentation 2 & Perlodidae & 2 \\
\hline Above Sedimentation 2 & Limnephilidae & 1 \\
\hline Above Sedimentation 2 & Chironomidae & 10 \\
\hline Above Sedimentation 3 & Decapoda & 1 \\
\hline Above Sedimentation 3 & Perlodidae & 1 \\
\hline Above Sedimentation 3 & Diptera pupa & 1 \\
\hline Above Sedimentation 3 & Chironomidae & 7 \\
\hline
\end{tabular}




\begin{tabular}{|c|c|c|}
\hline Below Sedimentation 1 & Tipulidae & 3 \\
\hline Below Sedimentation 1 & Decapoda & 1 \\
\hline Below Sedimentation 1 & Leptophlebiidae & 2 \\
\hline Below Sedimentation 1 & Hydropsychidae & 1 \\
\hline Below Sedimentation 1 & Heptageniidae & 15 \\
\hline Below Sedimentation 1 & Chironomidae & 1 \\
\hline Below Sedimentation 2 & Decapoda & 1 \\
\hline Below Sedimentation 2 & Tipulidae & 2 \\
\hline Below Sedimentation 2 & Heptageniidae & 1 \\
\hline Below Sedimentation 2 & Limnephilidae & 1 \\
\hline Below Sedimentation 2 & Corydalidae & 15 \\
\hline Below Sedimentation 2 & Chironomidae & 2 \\
\hline Below Sedimentation 2 & Leptophlebiidae & 1 \\
\hline Below Sedimentation 2 & Diptera pupa & 1 \\
\hline Below Sedimentation 2 & Elmidae & 1 \\
\hline Below Sedimentation 3 & Decapoda & 1 \\
\hline Below Sedimentation 3 & Hydropsychidae & 1 \\
\hline Below Sedimentation 3 & Nemouridae & 1 \\
\hline Below Sedimentation 3 & Ephemerellidae & 9 \\
\hline Below Sedimentation 3 & Leptophlebiidae & 1 \\
\hline Below Sedimentation 3 & Diptera adult & 2 \\
\hline Below Sedimentation 3 & Elmidae & 23 \\
\hline Below Sedimentation 3 & Chironomidae & 1 \\
\hline Below Sedimentation 3 & Heptageniidae & \\
\hline
\end{tabular}




\section{VITA}

Lenn Roberts was born on August $16^{\text {th }}, 1981$ in Richmond, Virginia. He lived in Richmond through high school, and attended Virginia Tech in 1999. He received a B.S. in Environmental Science from Virginia Tech in 2003, and attended Virginia Tech for graduate school in 2004. He currently is employed with the Kentucky Department for Environmental Protection in Frankfort, Kentucky. 